Review

\title{
Essential Oils and Their Individual Components in Cosmetic Products
}

\author{
Eduardo Guzmán ${ }^{1,2, * \mathbb{D}}$ and Alejandro Lucia ${ }^{3,4} \mathbb{D}$ \\ 1 Departamento de Química Física, Facultad de Ciencias Químicas, Universidad Complutense de Madrid, \\ Ciudad Universitaria s/n., 28040 Madrid, Spain \\ 2 Unidad de Materia Condensada, Instituto Pluridisciplinar, Universidad Complutense de Madrid, \\ Paseo de Juan XXIII 1, 28040 Madrid, Spain \\ 3 Instituto de Ecología y Desarrollo Sustentable (INEDES, CONICET-UNLu), Ruta 5 y Avenida Constitución, \\ Luján, Buenos Aires 6700, Argentina; luciaalejandro@yahoo.com.ar \\ 4 Centro de Investigación en Sanidad Vegetal (CISaV), Facultad de Ciencias Agrarias y Forestales, UNLP, \\ Calles 60 y 119, La Plata 1900, Argentina \\ * Correspondence: eduardogs@quim.ucm.es; Tel.: +34-913944107
}

check for

updates

Citation: Guzmán, E.; Lucia, A. Essential Oils and Their Individual Components in Cosmetic Products. Cosmetics 2021, 8, 114. https:// doi.org/10.3390/cosmetics8040114

Academic Editor: Enzo Berardesca

Received: 29 October 2021

Accepted: 28 November 2021

Published: 3 December 2021

Publisher's Note: MDPI stays neutral with regard to jurisdictional claims in published maps and institutional affiliations.

Copyright: (c) 2021 by the authors. Licensee MDPI, Basel, Switzerland. This article is an open access article distributed under the terms and conditions of the Creative Commons Attribution (CC BY) license (https:/ / creativecommons.org/licenses/by/ $4.0 /)$.

\begin{abstract}
The current consumer demands together with the international regulations have pushed the cosmetic industry to seek new active ingredients from natural renewable sources for manufacturing more eco-sustainability and safe products, with botanical extract being an almost unlimited source of these new actives. Essential oils (EOs) emerge as very common natural ingredients in cosmetics and toiletries as a result of both their odorous character for the design and manufacturing of fragrances and perfumes, and the many beneficial properties of their individual components (EOCs), e.g., anti-inflammatory, antimicrobial and antioxidant properties, and, nowadays, the cosmetic industry includes EOs or different mixtures of their individual components (EOCs), either as active ingredients or as preservatives, in various product ranges (e.g., moisturizers, lotions and cleanser in skin care cosmetics; conditioners, masks or antidandruff products in hair care products; lipsticks, or fragrances in perfumery). However, the unique chemical profile of each individual essential oil is associated with different benefits, and hence it is difficult to generalize their potential applications in cosmetics and toiletries, which often require the effort of formulators in seeking suitable mixtures of EOs or EOCs for obtaining specific benefits in the final products. This work presents an updated review of the available literature related to the most recent advances in the application of EOs and EOCs in the manufacturing of cosmetic products. Furthermore, some specific aspects related to the safety of EOs and EOCs in cosmetics will be discussed. It is expected that the information contained in this comprehensive review can be exploited by formulators in the design and optimization of cosmetic formulations containing botanical extracts.
\end{abstract}

Keywords: cosmetics; essential oils; formulations; fragrances; hair care; skin care

\section{Introduction}

Consumers are currently demanding cosmetic products with improved eco-sustainable profiles in relation to traditional one, which are commonly derived from petro-chemical sources and processes [1]. This has driven the research and development strategy of the cosmetic industry towards seeking green ingredients for manufacturing new products and reformulating others. This is mandatory to provide a suitable response to the demands of modern consumption patterns in relation to eco-sustainability without comprising the effectiveness of the final product nor the consumer satisfaction, which becomes a very complex challenge, overcoming the limits of cosmetic science, and needing a multidisciplinary approach [2,3]. Furthermore, the transition to a more "natural cosmetic" has also become a demand arriving from the current international regulations, which have banned the use of many traditional chemicals for the fabrication of products for human 
use, recommending their progressive substitution for other compounds, preferably from renewable natural sources, including both plants and microorganisms (biotechnological sources) [4-8]. Plants and microorganisms provide a broad range of cosmetically acceptable active ingredients, which can find different applications in the production of cosmetics and toiletries, e.g., protection against UV irradiation and pollution, fabrication of creams, production of fragrances, or mitigation of skin aging effects $[1,9,10]$.

It should be stressed that the use of natural ingredients in the fabrication of consumer products, and in particular cosmetics and toiletries, is not new [11]. However, it is only in recent years that "natural cosmetics" occupied such a big quota of the market of cosmetics and toiletries (around 40 billion USD by 2021 which corresponds to about $10 \%$ of the global market of cosmetics and toiletries) [12,13], and every day consumers are more attracted to the quality and effectiveness of products containing natural ingredients, including different botanical extracts and their individual components, as fragrances, preservatives or antioxidants [14-16]; compounds extracted from microalgae, e.g., vitamins, minerals, antioxidants or tyrosinase inhibitors $[17,18]$, and compounds isolated from fungi and bacteria, such as polysaccharides or biosurfactants (e.g., rhamnolipids or sophorolipids) which presents a growing interest within the hair care and conditioning industry $[6,7,19,20]$.

The current consumer interests, and market trends, have stimulated an important piece of research exploring the benefits associated with the incorporation of botanical extracts into the formulation of different cosmetic products. This is aimed to exploit their biological properties for manufacturing new products that can contribute to human health, beauty, and wellness. In particular, essential oils (EOs), and their individual components (EOCs), are accounted among the most appreciated products for fulfilling some of the requirements demanded for in the design of new products [21-24]. EOs have been widely incorporated in a broad range of cosmetic products, perfumes, and household products so that some of their properties, e.g., analgesic, antiseptic, and antimicrobial properties, but mainly their pleasant aroma, can be taken advantage of [25]. This review tries to provide an updated perspective on the current uses of EOs, and their individual components, in the cosmetic industry. Furthermore, some fundamental aspects related to the potential precautions required in the use of EOs and EOCs in the formulation of cosmetics and toiletries will be also discussed.

\section{General Aspects of EOs}

EOs are highly hydrophobic natural products extracted from aromatic plants (including flowers, roots, bark, leaves, seeds, peel, fruits, wood, and whole plants) which are widespread in the food and pharmaceutical industry, pest control, perfumery, cosmetics, and toiletries [16,26-29]. They form a broad family of substances characterized by a unique chemical profile defined by their individual components, the so-called essential oil components (EOCs) [29,30]. Therefore, a single essential oil should be considered as a complex mixture of bioactive compounds, with their final compositional profile, and hence their bioactivity, dependent on different factors: (i) method of extraction, drying and storage; (ii) time of harvest and climate conditions, and (iii) plant species and which part of the plant was used for their isolation [11]. This compositional richness presents a key characteristic in the broad range of essential oil applications, for contributing to improved health, hygiene, beauty and wellness [31].

EOs are commonly liquids with a lower density than the water. Furthermore, they are not water soluble, but they can be mixed with alcohols, ethers, and fats. EOs are mainly obtained from plants belonging to the angiosperm family (e.g., Apiaceae, Asteraceae, Lamiaceae, Lauraceae, Myrtaceae, and Rutaceae [1,32]), which play a very important role in defense, signaling or as part of their secondary metabolism [26,33]. Table 1 includes some examples of EOs, with their origin, properties, and active components. 
Table 1. Some examples of EOs classified as function of their origins. Furthermore, the properties of the EOs and active compounds are also reported. Adapted from Raut et al. [34], Copyright (2014), with permission from Elsevier.

\begin{tabular}{|c|c|c|c|c|}
\hline Plant Family & Essential Oil & Properties & Active Compounds & References \\
\hline Apiaceae & $\begin{array}{l}\text { Carum nigrum (Black caraway) } \\
\text { Anethum graveolens (Dill) } \\
\text { Apium graveolens (Celery) } \\
\text { Foeniculum vulgare (Fennel) } \\
\text { Pimpinella anisum (Anise) } \\
\text { Cuminum cyminum (Cumin) } \\
\text { Corriandrum sativum (Coriander) }\end{array}$ & $\begin{array}{l}\text { Antibacterial } \\
\text { Antifungal } \\
\text { Antiviral }\end{array}$ & $\begin{array}{l}\text { Citronellol; curzerene; limonene; } \\
\text { linalool; }(E) \text { - } \beta \text {-ocimene; } \alpha \text {-pinene; } \\
\text { sabinene; terpinolene }\end{array}$ & [35-37] \\
\hline Asteraceae & $\begin{array}{c}\text { Artemisia Judaica } \\
\text { Artemisia annua } \\
\text { Artemisia absinthium (Wormwood) } \\
\text { Artemisia dracunculus (Tarragon) }\end{array}$ & $\begin{array}{l}\text { Antifungal } \\
\text { Antiviral }\end{array}$ & $\begin{array}{c}\text { camphor; } \beta \text {-carophyllene; } \\
\text { 1,8-cineole; } \mathrm{p} \text {-cymene; limonene; } \\
\beta \text {-pinene; } \alpha \text {-thujane; } \beta \text {-thujane }\end{array}$ & {$[38,39]$} \\
\hline Lamiaceae & $\begin{array}{c}\text { Origanum vulgare (Origano) } \\
\text { Melissa officinalis (Lemon balm) } \\
\text { Salvia officinalis (Sage) } \\
\text { Mentha longifolia (Wild Mint) } \\
\text { Mentha piperita (Peppermint) } \\
\text { Mentha spicata (Spearmint) } \\
\text { Ocimum basilicum (Sweet Basil) } \\
\text { Rosmarinus officinalis (Rosemary) } \\
\text { Lavandula officinalis (Lavender) } \\
\text { Salvia sclarea (Sage Clary) }\end{array}$ & $\begin{array}{l}\text { Antibacterial } \\
\text { Antifungal } \\
\text { Antiviral } \\
\text { Anti- } \\
\text { inflammatory } \\
\text { Antioxidant }\end{array}$ & $\begin{array}{l}\text { carvacrol; p-cymene; geraniol; } \\
\text { germacrene; limonene; linalool; } \\
\gamma \text {-terpinene; terpine-4-ol; thymol }\end{array}$ & {$[40,41]$} \\
\hline Lauraceae & Cinnamomum verum (Cinnamon) & $\begin{array}{l}\text { Antimicrobial } \\
\text { Anti- } \\
\text { inflammatory }\end{array}$ & $\begin{array}{c}\text { anetole; anisole; } \delta \text {-cadinene; } \\
\alpha \text {-cadinol; } \beta \text {-caryophyllene; } \\
\text { 1,8-cineole; } \alpha \text {-cubebene; linalool; } \\
\gamma \text {-terpinene; terpinen-4-ol }\end{array}$ & {$[42,43]$} \\
\hline Myrtaceae & $\begin{array}{l}\text { Syzigium aromaticum (Clove) } \\
\text { Thymus vulgaris (Thyme) } \\
\text { Melaleuca alternifolia (Tea tree) } \\
\text { Eucalyptus globulus (Blue gum) } \\
\text { Myristica fragrans (Nutmeg) }\end{array}$ & $\begin{array}{l}\text { Antibacterial } \\
\text { Antifungal } \\
\text { Antiviral } \\
\text { Anti- } \\
\text { inflammatory }\end{array}$ & $\begin{array}{l}\text { 1,8-cineole; citronellol; geraniol; } \\
\text { neral; sabinene; } \gamma \text {-terpinene }\end{array}$ & [44] \\
\hline Rutacea & $\begin{array}{l}\text { Citrus medica (Lemon) } \\
\text { Citrus. paradisi (Grape fruit) }\end{array}$ & $\begin{array}{l}\text { Antibacterial } \\
\text { Antifungal }\end{array}$ & $\begin{array}{l}\text { citronellol; limonene; linalool; } \\
\text { linalyl acetate; } \beta \text {-phellandrene }\end{array}$ & {$[45,46]$} \\
\hline
\end{tabular}

EOs should be considered as a renewable bio-resource of active ingredients that can be exploited for the production of eco-sustainable products, with their antioxidant, bactericidal, virucidal, fungicidal, antiparasitical, insecticidal, and medicinal properties being a very important benefit for this type of applications [47-49]. In particular, the bactericidal and fungicidal role of some of their individual components allow their inclusion in the formulation of a broad range of cosmetic products, e.g., creams, gels, and ointments, without needing the addition of chemical preservatives [50]. It is worth mentioning that EOs present several drawbacks, including their high volatility, poor solubility in water, and their thermal and chemical labilities (most of these molecules are fragile to oxidation upon exposure to the environment), which makes their handling difficult for a rational design of cosmetic products $[24,26,51]$, and requires careful control of their packaging, conditioning, and storage conditions. Furthermore, the role of EOs, and their individual components, in the formulations is not always positive, representing a potential source of allergenic reactions, and, hence, a careful quantification of their maximum concentrations in a specific formulation is necessary to ensure the production of safe cosmetic products [30].

\subsection{Chemical Composition of EOs}

From a chemical point of view, EOs are very complex mixtures of low molecular weight volatile compounds (in some cases more than 100), the so-called essential oil 
components (EOCs), which appear at quite different concentrations [24]. However, the compositional richness of EOs is not reflected in their biological properties, which are commonly determined by two or three components appearing at the highest concentrations $(20-70 \% w / w)$ [34]. On the other side, the chemical composition, and hence the quality of a specific essential oil, depends on different factor, including genetic aspects, time of harvest, crop location, part of the plant used or production method [51,52].

The main components of most EOs are lipophilic terpenoids, phenylpropanoids (aromatic compounds), and short-chain aliphatic hydrocarbon derivatives (terpenes). The latter include hydrocarbons, esters, aldehydes, ketones, alcohols, oxides, phenols-derived aromatic or ethers $[11,51,53]$. Figure 1 shows some representative molecular structures of different essential oil components (EOCs) that can appear in EOs.

The composition of EOs is associated with the existence of specific biosynthetic pathways in plants [54]. These pathways are commonly differentiated depending on the specific chemical nature of the component, i.e., the biosynthesis of the different types of essential components follows very specific routes [11]. Thus, aromatic phenylpropanoids are obtained from the shikimic acid pathway, which results in the formation of phenylalanine, terpenoids derived from the isopentenyl diphosphate (IPP), and its isomer dimethylallyl diphosphate (DMAPP) [53,55]. On the other hand, terpenoids are composed by different isoprene units $\left(\mathrm{C}_{5} \mathrm{H}_{8}\right)$ which are commonly assembled in a head-to-tail fashion following a direct assembly process, or by cyclization, rearrangements, or other types of conversions from aliphatic isoprenoid precursors [51]. The biosynthesis of terpenes occurs by repetitive addition of IPP units to create prenyldiphosphate precursors which are modified by terpene specific synthethases to obtain the terpene skeleton. These undergo secondary enzymatic modification, generally trough a redox process, to obtain the final terpene molecules with specific chemical structures and properties [11].

It should be noted that together with the specific compositional richness of EOs associated with the biosynthetic pathways, it is possible to obtain extracts with different compositions from a plant type depending on the methodology used for their isolation, i.e., the final composition of the EOs may change depending of the approaches used for their extraction. This may be rationalized as a result of the specific properties of the individual components contained on the essential oil, mainly their volatility. Thus, genuine essential oils obtained by distillation contain a high amount of low volatile components, e.g., diterpenes, whereas compounds such as terpenoids, e.g., sterols or carotenoids, remain in the non-volatile fraction contained in plant resins or gums, remaining as a residue in the distillation process [51]. It should be noted that the weight ratio between volatile and non-volatile compounds is strongly dependent on the specific essential oil, and range from the 99:1 of grape fruit oil to the 60:40 of bergamot oil [56].

\subsection{Isolation of $E O s$}

EOs are extracted from tiny secretory structures distributed in different plant parts, e.g., leaves (eucalyptus, sage, thyme); berries (juniper); grasses (palmarosa, citronella); flowering tops (lavender); petals (rose, jasmine, ylang-ylang); roots (vetiver); fruit (orange, lemon); resins (frankincense, myrrh); wood (cedar, sandalwood, rosewood); bark (cinnamon); seeds (almond, cumin); rhizome (ginger, galangal); and peels (lemon, lime, orange) [57].

The isolation, concentration, and purification of essential oils from the above structures can be done by different physico-chemical procedures, which can be traditionally divided into three groups: (i) distillation (hydro-distillation, steam distillation or dry distillation); (ii) extraction (microwave and ultrasound assisted extraction, solvent extraction, supercritical fluid extraction, enfleurage or maceration); and (iii) pressing (mechanical or cold pressing) $[28,57,58]$. 


\section{Terpenes}

-Monoterpenes

Carbure monocyclic p-cymene

Carbure bicyclic<smiles>Cc1ccc(C(C)C)cc1</smiles>
sabinene $\alpha$-pynene $\beta$-pynene<smiles>C=C1CCC2(C(C)C)CC12</smiles><smiles>C=C1CCC2CC1C2(C)C</smiles>

Alcohol acrylic citronellol<smiles>CC(C)=CCC/C(C)=C/CO</smiles>

\section{Phenol}

carvacrol<smiles>CC(C)=CCC[C@H](C)CCO</smiles>

-Sesquerpitenes<smiles>CC(C)=CCC/C(C)=C/CC/C(C)=C/CO</smiles><smiles>C=C1CCC=C(C)CCC2C1CC2(C)C</smiles>

\section{Aromatic compounds}<smiles>CC(C)(C)C=CC=Cc1ccccc1</smiles>

Alcohol

cynnamyl alcohol

Phenol

Phenol<smiles>Cc1ccc(C(C)C)cc1O</smiles><smiles>CC(C)c1ccc(Br)cc1O</smiles>

Methoxy derivates anethole<smiles>C/C=C/c1ccc(OC)cc1</smiles><smiles>OC/C=C/c1ccccc1</smiles><smiles>C=CCc1ccc(O)cc1</smiles>

eugenol

Methoxy derivates estragole<smiles>C=CCc1ccc(OC)cc1</smiles>

Methylene dioxy compounds safrole<smiles>C=CCc1ccc2c(c1)OCO2</smiles>

\section{Terpinoids}

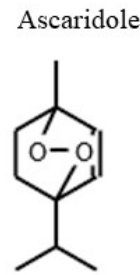<smiles>CC(C)[C@H]1CC[C@@H](C)CC1O</smiles>

Figure 1. Some representative chemical structures of commonly found individual components of EOs. Reproduced from Bakkali et al. [11], Copyright (2008), with permission from Elsevier. 
The isolation of essential oils by pressing may be considered the seminal procedure for obtaining essential oils, and it currently continues being a suitable alternative for obtaining essential oils of relatively cheap raw materials, e.g., citrus peel. However, the existence of plant structures where the oil content is relatively reduced, e.g., flowers, or the lability of certain compounds to high temperatures such as those used in distillation processes, make it necessary to seek alternatives for essential oil extraction. A suitable procedure in the above cases may be the extraction with organic solvents, either pure organic solvents or their mixtures [56]. Organic extraction in ethanol during $30 \mathrm{~h}$ was used for isolating Australian tea essential oil [59]. Other solvents used for the essential oil extraction are dicloromethane, hexane, methanol or mixtures of pentane and dicloromethane [60-63]. It should be noted that the extraction using organic solvents present several drawbacks: (i) it is time consuming; (ii) the low selectivity of organic solvents, which leads to extraction to the so-called concretes, i.e., complex mixtures of essential oil, waxes, resins, and other lipophilic plant materials, and (ii) the remaining residues of organic solvents. The former drawback can be overcome by applying ultrasounds or microwaves that allow reducing the time required for the extraction procedure down to 20-30 $\mathrm{min}[64,65]$.

An alternative way to overcome the problems of selectivity associated with the extraction process, and the existence of residues associated with the use of organic solvents, is the use of an extraction process using supercritical fluids, i.e., fluids above their critical points [66]. The application of supercritical fluids for extraction relies in the combination of gas-like mass transfer properties and liquid-like solvating capacity, even though their diffusion coefficients are higher than those of liquids. The low toxicity and chemical inertness of supercritical $\mathrm{CO}_{2}$ make it the most common supercritical fluid used for extraction of natural products. Some examples of the application of supercritical fluids to the isolation of essential oils can be found in the extraction of oil from Moringa oleifera seeds [67], rosemary [68], peppermint [69], or cardamom [70]. Furthermore, the extraction using supercritical fluids can also be exploited for enhancing the essential oil quality, through fractionation and determination processes [56].

Distillation procedures are also extensively used in the isolation of essential oils from their natural sources [71,72]. For this purpose, the plants or their specific part are incorporated over water into a distillation apparatus. Thus, as the water is heated, the steam passes through the plant material, enabling the vaporization of the volatile compounds. The obtained vapor circulates along a cooling coil, where it is condensed back to the liquid form and collected into a vessel. However, the use of distillation procedures for isolating essential oils presents three important drawbacks: (i) the possible losses of thermolabile components; (ii) the difficulties associated with its automatization, and (iii) the long time required for the isolation process. It should be noted that the use of distillation under vacuum can contribute to reduce the problems associated with the degradation induced by temperature of labile components [56].

It is worth mentioning that up to the date there are no techniques providing the required versatility for allowing the isolation of essential oils with characteristics tuned at will. Therefore, the choice of a suitable technique for obtaining essential oils will depend on the final application of the obtained extracts, avoiding the degradation of compounds or the isolation of complex mixtures with undesired compounds.

\subsection{Quality of EOs}

The demand of pure EOs and EOCs in different industrial and technological fields, e.g., production of fragrances and flavors, cosmetic industry, pest control, phytomedicine, and aromatherapy, has undergone an important growth in the last years [24,73]. However, the isolation of essential oils commonly presents a very reduced yield in relation to the mass of raw materials, which makes difficult to cover the large scale consumption of international markets [23]. Therefore, the adulteration and contamination of EOs are problems with growing importance in recent years, and, hence, the essential oil authentication is crucial for both industries and final consumers [74,75]. This requires the introduction of a standard 
definition of what an essential oil is. The "Association Française de Normalisation" (AFNOR) and the European Pharmacopoeia (Ph. Eur.) define essential oils as manufactured products from pure, identified raw materials of plant origin, obtained using hydrodistillation, steam distillation, mechanical processes, or dry distillation for some woods [75].

The standardization procedures try to define a series of standards of quality. However, a non-compliance result in relation to the standardization tests is not always a signature of product adulteration. This is because different aspects, including aging, process or storage, may lead to racemization or polymerization processes, which result in a change of the essential properties without undergoing a true adulteration [76].

There are different adulteration cases reported, which include the addition of nonvolatile ingredients, cheaper synthetic or natural compounds, volatile compounds or essential oils from other natural sources or vegetable oil $[23,75]$. On the other side, adulteration of essential oils by total or partial substitution of the plant for other species is also a very common practice $[73,77]$. It should be stressed that the adulteration results in a reduction of the essential oil quality, and in many cases, can lead to safety issues. Therefore, the authentication is essential for ensuring consumer protection and the quality of the production processes of essential oils, affecting to standardization and regulatory aspects [78].

It should be noted that the concentration of adulterants added to essential oils is frequently relatively low $(5-8 \% w / w)$, avoiding their detection by common analytical procedures [79]. The evaluation of the adulteration is commonly performed following two different approaches: (i) detection of product fingerprints, and (ii) determination of specific marker in the products [75]. Thus, it is possible to evaluate the conformity of the product in relation to the specifications of the regulatory entities, ensuring identity, quality, safety and efficiency of the obtained essential oil [80].

There are two different levels for evaluating the quality of essential oils. The first consists of the examination of the organoleptic properties of the product by a sensory-analysis panel [81]. The second level relies in the determination of different physico-chemical constants, including specific gravity, refractive index, and optical rotation. Furthermore, the solubility of the essential oil in specific solvents (e.g., ethanol) can also be considered an important parameter for determining any potential adulteration. On the other hand, the analysis of certain chemical aspects, including the acidity and the ester, alcohol, aldehyde or ketone concentrations may also provide very valuable information for determining the purity of a specific essential oil [82].

It is worth mentioning that the simple determination of physico-chemical characteristics of the extracts may not be enough for evaluating some adulterations, and the use of more powerful analytical techniques may be required, e.g., gas and liquid chromatography, mass spectrometry, magnetic nuclear resonance, raman spectroscopy or infrared spectroscopy [83-87]. Figure 2 summarized the different steps for characterization of the purity of essential oils together with the advantages and disadvantages associated with the different analytical methodologies.

It is true that the pool of analytical techniques allowing the detection of essential oil adulteration, and their power do not stop their growth in recent years. However, adulteration methods have also improved, which makes necessary a case-by-case analysis due to the absence of general detection methods. 


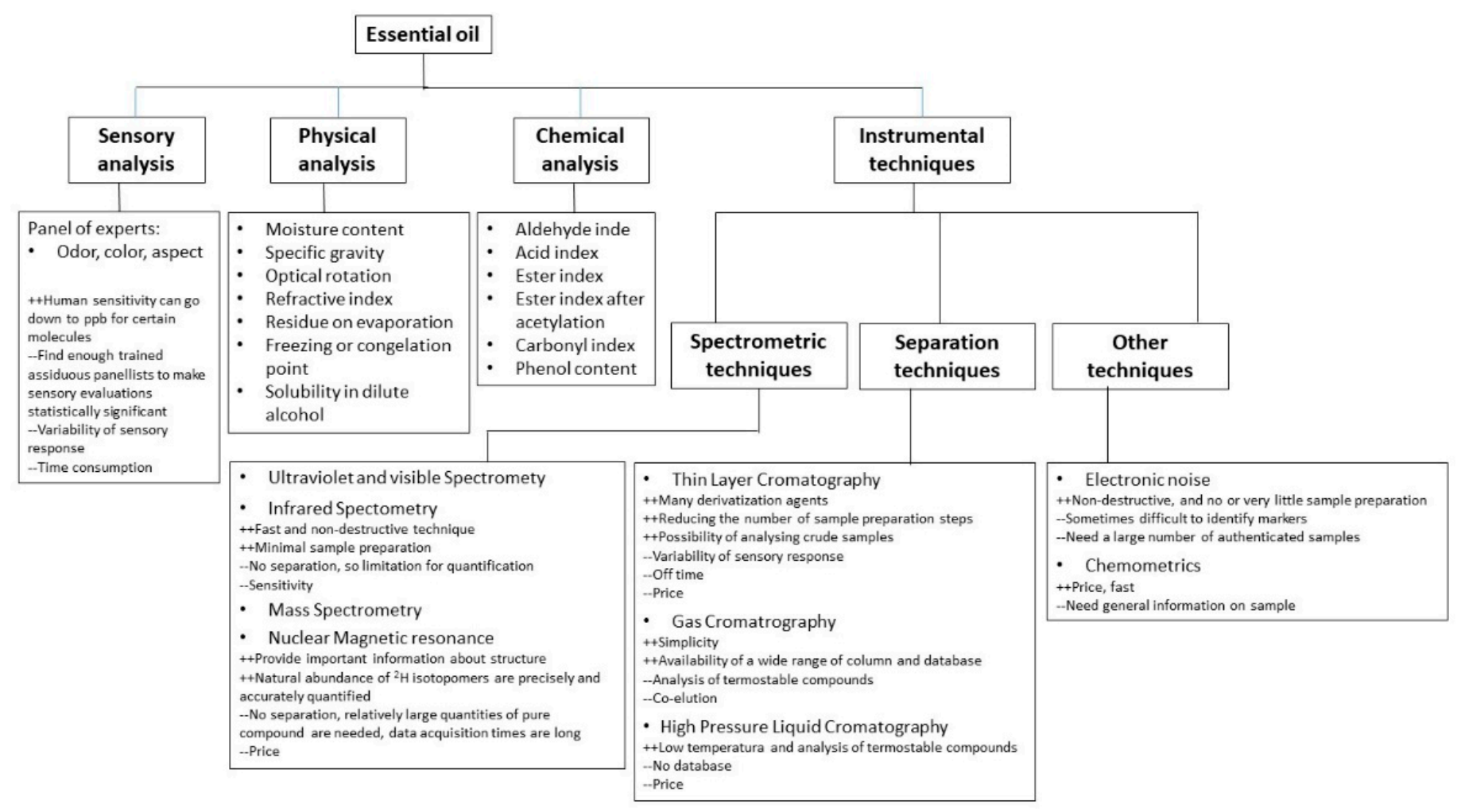

Figure 2. Summary of the different procedures used for evaluating the quality of essential oils together with some of their main advantages and disadvantages. Reproduced from Do et al. [75], Copyright (2015), with permission from Elsevier.

\section{EOs and EOCs in Fragrances}

For a long time, the application of EOs and EOCs in cosmetics and toiletries occurred mainly in the preparation of fragrances, but this does not mean that this type of substances cannot be included in formulations with other functions [88]. EOs and EOCs are frequently added for providing aroma to cosmetic products, which commonly is considered as a benefit because consumers prefer products having a pleasant aroma rather than nonaromatized products [89].

EOs themselves may be considered as creative fragrances constituted by a complex blend of components providing a characteristic odor. Following the concept of the nature, the process for providing different fragrances to commercial formulations requires to blend different EOs to obtain a specific scent [90]. The industry of fragrances tends to classify the aromas as functions of their odorous characteristics, volatility, and diffusion rate in the air, which leads to three different levels defined as top, middle or base notes [23]. Thus, highly volatile EOs provide aromas classified as top notes, and are responsible for the first perceptible odors and freshness of the blend forming the fragrance. They are commonly light scents which fade first, including bergamot, juniper, cinnamon or gardenia [91].

Middle notes are commonly associated with spicy or floral aromas, providing the body to the products. This type of aromas includes those obtained from ylang-ylang, geranium, lavender, jasmine, and clove. On the other side, the base notes provide to the perfume the depth and the duration. This requires to use EOs with very low volatility, including myrrh, vanilla, sandalwood, and frankincense [23,92].

EOs and their individual components should be considered among the most important substances included in perfumes and other odorous cosmetic products, existing a broad range of components of perfumes. This makes possible the design of many different formulations. In particular, the market of fragrances and flavors has available for the above purpose more than 300 EOs from about 3000 plant species [93]. This is important because the inclusion of fragrances in cosmetic products, and not only in perfumes, is often times required to mask the unpleasant scent associated with some of the compounds (fatty 
acids and oils or surfactants) used in the production of cosmetic products [92], e.g., EOs are included in antidandruff shampoos for masking the unpleasant odor of this type of products, offering a subtle, fresh and natural aroma [94]. Therefore, it may be assumed that EOs and EOCs are used to improve the sensorial perception, evoking particular moods or sensations, e.g., cleanliness. Furthermore, fragrances may be also exploited with a psychological effect.

\section{Applications of EOs and EOCs in Cosmetic Products for Hair and Skin Care}

The inclusion of EOs, and their individual components, in the manufacturing of a broad range of cosmetic products has been stimulated by the recognized effectiveness of these types of substances in health and beauty, providing different benefits to the formulation. These benefits are exemplified in the antiseptic properties of some essential oils (e.g., lemon and orange essential oils) associated with their high content on terpenes [95], such as limonene, which make them very promising active ingredients for skin and hair care [16]. Table 2 summarizes some of the potential applications of EOs in the design of cosmetic formulations.

Table 2. Potential application of some EOs in the design of different cosmetic formulations.

\begin{tabular}{|c|c|c|c|c|c|c|}
\hline Application & Essential Oil & Plant & Main Components & Properties & Function & References \\
\hline \multirow{5}{*}{ Skin care } & Chamomile & $\begin{array}{l}\text { Matricaria } \\
\text { chamomilla }\end{array}$ & $\begin{array}{c}\alpha \text {-bisabolol; bisabolol oxide; } \\
\text { bisabolon oxide; chamazulene; } \\
\text { 1,8-Cineole; } \beta \text {-farnesene; } \alpha \text {-Terpineol }\end{array}$ & $\begin{array}{l}\text { anti-inflammatory } \\
\text { wound healing }\end{array}$ & $\begin{array}{l}\text { anti-acne } \\
\text { anti-aging }\end{array}$ & [96-98] \\
\hline & Sandalwood & $\begin{array}{l}\text { Santalum } \\
\text { spicatum }\end{array}$ & $\begin{array}{c}\alpha \text {-bisabolol; }(E) \text {-farnesol; } \\
\text { nuciferol; } \alpha \text {-santalol; } \beta \text {-santalol }\end{array}$ & $\begin{array}{l}\text { antiseptic } \\
\text { antioxidant }\end{array}$ & anti-aging & {$[99,100]$} \\
\hline & $\begin{array}{l}\text { Evening } \\
\text { primrose }\end{array}$ & $\begin{array}{l}\text { Oenothera } \\
\text { biennis }\end{array}$ & $\begin{array}{c}\beta \text {-amyrin; } 1 \text {-hexacosanol; linoleic acid; } \\
\gamma \text {-linolenic acid; } 1 \text {-tetracosanol; squalene }\end{array}$ & $\begin{array}{l}\text { antibacterial } \\
\text { antioxidant }\end{array}$ & $\begin{array}{l}\text { anti-wrinkles } \\
\text { moisturizer } \\
\text { anti-acne }\end{array}$ & [101-103] \\
\hline & Camellia & $\begin{array}{l}\text { Camellia } \\
\text { japonica }\end{array}$ & $\begin{array}{c}\beta \text {-amyrin; cycloartenol; } \\
\text { lanosterol; lupeol; } \beta \text {-sitosterol; squalene }\end{array}$ & $\begin{array}{c}\text { antibacterial } \\
\text { antioxidant }\end{array}$ & $\begin{array}{l}\text { anti-aging } \\
\text { moisturizer }\end{array}$ & [104-106] \\
\hline & Rosemary & $\begin{array}{l}\text { Rosmarinus } \\
\text { officinalis }\end{array}$ & $\begin{array}{c}\text { borneol; camphene; camphor; } \\
\beta \text {-caryophyllene; } 1,8 \text {-cineole; p-cymene; } \\
\text { limonene; linalool; myrcene; } \alpha \text {-pinene; } \\
\beta \text {-pinene; } \alpha \text {-terpineol }\end{array}$ & $\begin{array}{l}\text { antibacterial } \\
\text { antioxidant }\end{array}$ & anti-acne & {$[107,108]$} \\
\hline \multirow{5}{*}{ Hair care } & Sweet orange & $\begin{array}{l}\text { Citrus } \\
\text { sinensis }\end{array}$ & $\begin{array}{c}\text { limonene; myrcene; } \alpha \text {-pinene; } \\
\beta \text {-pinene; sabinene }\end{array}$ & $\begin{array}{l}\text { antibacterial } \\
\text { antioxidant }\end{array}$ & antidandruff & {$[109,110]$} \\
\hline & Lavender & $\begin{array}{l}\text { Lavandula } \\
\text { officinalis }\end{array}$ & $\begin{array}{l}\text { borneol; caryophyllene; lavandulol; } \\
\text { lavandulol acetate; linalool; linalyl } \\
\text { acetate; } \alpha \text {-terpineol; terpinene-4-ol }\end{array}$ & $\begin{array}{c}\text { antibacterial } \\
\text { antioxidant }\end{array}$ & $\begin{array}{l}\text { hair growth } \\
\text { conditioning }\end{array}$ & [111] \\
\hline & Peppermint & $\begin{array}{l}\text { Mentha } \\
\text { piperita }\end{array}$ & $\begin{array}{c}\text { carveone; } 1,8 \text {-cineole; } \\
\text { limonene; menthol; menthone; } \\
\text { methyl acetate; neomenthol }\end{array}$ & $\begin{array}{c}\text { antibacterial } \\
\text { antioxidant }\end{array}$ & $\begin{array}{l}\text { hair growth } \\
\text { conditioning }\end{array}$ & [112-114] \\
\hline & Thyme & $\begin{array}{l}\text { Thymus } \\
\text { vulgaris }\end{array}$ & $\begin{array}{l}\alpha \text {-cadinene; } \gamma \text {-cadinene; } \delta \text {-cadinene; } \\
\alpha \text {-cadinol; } \delta \text {-cadinol; } \beta \text {-caryophyllene; } \\
\text { p-cymene; elemol; } \beta \text {-eudesmol; } \\
\text { germacrene; limonene; } \gamma \text {-muurulene; } \\
\text { myrcene; trans- } \beta \text {-ocimene; } \beta \text {-pinene; } \\
\quad \gamma \text {-terpinene; } \alpha \text {-terpineol }\end{array}$ & $\begin{array}{c}\text { antibacterial } \\
\text { antioxidant }\end{array}$ & $\begin{array}{l}\text { antidandruff } \\
\text { hair growth }\end{array}$ & {$[115,116]$} \\
\hline & Bergamot & $\begin{array}{l}\text { Citrus } \\
\text { bergamia }\end{array}$ & $\begin{array}{l}\text { bergamottin; bergapten; citropten; } \\
\text { limonene; linalool; linalyl acetate; } \\
\alpha \text {-pinene; } \beta \text {-pinene; } \gamma \text {-terpinene }\end{array}$ & $\begin{array}{c}\text { antibacterial } \\
\text { anti-inflammatory }\end{array}$ & $\begin{array}{l}\text { antidandruff } \\
\text { hair growth }\end{array}$ & {$[116,117]$} \\
\hline
\end{tabular}

EOs and EOCs may affect the normal function of skin cells upon topical application, providing to the formulations anti-acne, anti-aging, skin lightening, and sun protection characteristics [24,118-121]. Furthermore, they can introduce antibacterial, antifungal, antiinflammatory and antioxidant properties to the formulations which may induce benefits on the hair scalp, and promote an increase of the hair shaft density or cleaning effect on the hair bulb and strengthening of the whole capillary fiber (bulb/stem system) $[94,122]$. 
Furthermore, EOs and EOCs are natural preservative agents which can be included into commercial products alone or in combination with other preservatives, providing protection against bacteria and fungi [123-125].

\subsection{Potential Applications EOs and EOCs in Hare Care}

The current knowledge on the potential applications of EOs and EOCs in hair care is scarce. However, there are several studies reporting that EOs and EOCs can be good alternatives or effective complements for hair care, especially considering their effectiveness on the reparation of damages in hair fibers [116,126]. The most accepted mechanism accounting for the activity of EOs and EOCs in hair reparation considers that cosmetic formulations containing EOs and EOCs present a topical action upon their application on the scalp. This is possible because some EOCs can penetrate into the scalp, supplementing the nutritional pathways, which stimulates the growth of the hair follicles, moistures the hair root and strengthens the capillary fibers. On the other side, the mechanism associated with the activity of EOs and EOCs on the hair shaft is far from clear [116].

Moreover, some EOs and EOCs can be used for brightness intensification and color fixation and others can provide shine and conditioning effects $[127,128]$. The latter can be obtained by adding EOs from rosemary (Rosmarinus officinalis) or chamomile (Matricaria chamomilla) in shampoo or conditioner formulations. This role of EOs in hair conditioning can be understood considering that individual components of essential oils can penetrate in the scalp quickly, which nourishes the hair follicles, contributes to the hair nutrition, moisturizes the hair roots, strengthens the hair, and helps in the removal of undesired molecules blocking the pores [116]. The existence of different commercial cosmetic formulations exploiting the properties of Nigella sativa as a cream, oil or shampoo for conditioning purposes should be noted [129].

EOs also have a very important role in the stimulation of hair growth and in the prevention of the hair loss $[15,121,130,131]$. Thus, the topical application of formulations containing peppermint oil extracted from Mentha piperita at a relatively low dose $(3 \% w / w)$ allows the stimulation of hair growth [112]. Similar effects were found upon the application of formulations containing rosemary oil in a concentration allowing a final content of $3.7 \mathrm{mg}$ of 1,8-cineole per $\mathrm{mg}$ of final product. This type of formulation is effective against alopecia, similar to formulations containing minoxidil at $2 \% w / w$ [132]. These results can be explained considering that the antioxidant characteristic of phenolic compounds may reduce the oxidative stress inducing alopecia. Furthermore, essential oils contribute to the blood circulation in the hair follicles, protecting the vascularization of hair dermal papilla [112,116]. Another important contribution of some essential oil components to the hair growth is associated with their role in the control of the expression of specific genes associated with the regulation of this process [133].

Sahraie-Rad et al. [116] proved a mixture of different EOs (Punica granatum, Rosmarinus officinalis, Matricaria chamomilla, Urtica dioica, Mentha piperita, and Salvia officinalis) and some conventional chemicals for preparing an antidandruff shampoo, and found that the inclusion of EOs in shampoo formulations enhanced the efficacy of the product without any additional side effect. This was ascribed to the combination of the antifungal properties of the EOs, which contribute to the removal of the dandruff origin, with the anti-inflammatory properties of some EOCs, e.g., menthol and $\alpha$-bisabolol in the essential oils of Mentha piperita and Matricaria chamomilla, respectively. Similar results related to the ability of EOs for dandruff removal have been reported for other essential oils, e.g., thyme oils (Thymus vulgaris), lavender (Lavandula angustifolia), sage (Salvia sclarea), or bergamot (Citrus bergamia) $[116,130]$.

The antidandruff efficiency of a shampoo containing a mixture of EOs from different sources (Rosmarinus officinalis, Vetiverla zizanioides, Nigella sativa, Santalum album, Ficus bengalensis, Citrus limon, and oil of Melaleuca leucadendron) was proved by Ravichandran et al. [134], demonstrating that the high effectiveness of the prepared formulation may be associated with the synergistic antifungal, anti-inflammatory, and local immune-stimulatory actions of 
specific EOCs. This allows formulating an effective and safe herbal antidandruff shampoo by mixing several essential oils. Similar conclusions were reported by Halith et al. [135] using a combination of a different set of EOs. Furthermore, they compared the effectiveness of their essential oil-based shampoo with that obtained for a commercial formulation, finding that the experimental formulation may be considered as a cost-effective competitor to those currently commercialized. Another important disease related to the dysfunction of capillary physiology is the seborrhea, which is associated with oiliness of the hair fibers. EOCs can be also used for a partial mitigation of this type of pathology [136]. This is possible because the antimicrobial activity of specific essential oil compounds can reduce the proliferation of the bacteria associated with seborrhea emergence.

\subsection{Potential Application of EOs and EOCs in Skin Care}

In recent years EOs and EOCs have become very popular ingredients for skin care purposes. This growing interest for exploiting these molecules in skin care products tries to take advantage of some of their biological properties, e.g., antimicrobial, anti-inflammatory, and antioxidant, for keeping skin youthful, healthy, and fresh, enabling its protection from environmental damages $[130,137]$. In particular, the use of EOs due to their lipophilic character can contribute the maintenance of both the skin microbiota, which presents a very critical role on the maintenance of the skin health, and the protective role of the stratum corneum $[138,139]$. Table 3 summarized some potential applications of different essential oils in skin care.

One of the most common uses of EOs in skin care is to prevent the emergence of acne, taking advantage of the ability of EOs for inhibiting the proliferation of Propionibacterium acnes [140-143]. Furthermore, EOs can contribute to the reduction of the inflammation and post-acne scar formation. Lertsatitthanakorn et al. [142] demonstrated that the antibacterial power of citronella grass essential oil against Propionibacterium acnes, combined with its good free radical scavenging activity and its ability of inhibiting the activity of the 5LOX enzyme, contributed to the reduction of the inflammatory processes associated with acne emergence. Mahant et al. [144] showed that the topical application of the essential oil of Cymbopogan martini (palmarosa oil) at a relative low dose also presents a high potential for mitigating the effects of the acne, which was ascribed to the role of its main component (geraniol). This presents a strong antibacterial character, contributing to the inhibition of the tyrosinase activity and the reduction of the cytokine. Xiao et al. [145] demonstrated that borneol may be a potential candidate for developing natural formulations with an anti-inflammatory character for skin care, becoming an effective alternative to conventional products containing antibiotics and synthetic anti-inflammatory agents. Tao et al. [143] deepened on the origin of the activity of artemisin essential oil (Artemisia annua) in the mitigation of acne, and found a certain degree of correlation between the concentration of terpenes and the anti-acne activity of EOs. The terpenes provide several benefits to the skin, and help reduce the proliferation of microorganisms implicated in the emergence of acne and eczema. Furthermore, it was found that artemisin essential oil contributed in blocking the hormonal pathways associated with the emergence of inflammatory processes associated with acne emergence.

Nawarathne et al. [146] designed and tested a cosmeceutical formulation for a topical gel against acne emergence containing Nigella sativa essential oil. The composition per $100 \mathrm{~g}$ of formulations was the following: carbopol 940 (1.10 g); phenoxyethanol (1.00 g); glyceryn ( $3.00 \mathrm{~g})$; polyethylene glycol $(0.05 \mathrm{~g})$; Fuller's earth $(0.10 \mathrm{~g})$; cetyl alcohol $(0.01 \mathrm{~g})$; ethylenediaminetetraacetic acid (0.10); Nigella sativa extract (5.00-15.00 g); triethanolamine and rosewater. This type of formulations presents strong antibacterial activity against acne-causing bacteria, with this activity being stronger as the concentration of the essential oil is increased. Furthermore, the obtained formulation presents higher efficacy than formulations containing synthetic anti-acne products.

The use of geranium essential oil is highly efficient against different dysfunctions on the skin physiology, including acne, dry skin, skin aging, dermatitis or eczema. This is 
commonly ascribed to the high concentration of specific EOCs, among which are included linalool, geranyl formate, citronellol, and geraniol, which contribute to the restoration of the skin native elasticity and the enhancement of the blood circulation to the skin [147]. Furthermore, geranium essential oil allows regulating the hydration balance on the skin and the renewal of skin cells, which are very important aspects for mitigating the effects of acne [148]. Furthermore, geranium essential oils contribute to the minimization of different spots on the skin, e.g., dark spots, red marks, age spots or marks from skin irritation [141].

The effects of the skin aging can be also prevented by the use of other EOs as showed Rahmi et al. [149]. They found that different EOs (patchouli, nutmeg, citronella, and clove oils) upon topical application allow a significant mitigation of the skin aging induced by the exposure to UVB radiation, reducing the wrinkle formation. It should be noted that the specific composition of the essential oils modify their performance in skin care. In particular, for the set of tested EOs, the anti-aging properties follows the sequence: clove $>$ patchouli $>$ nutmeg $>$ citronella oil.

It should be noted that the application of EOs for skin care must consider the allergenic power of these molecules for fixing their optimal doses. EOs of Pluchea dioscoridis and Erigeron bonariensis were also found to induce a strong anti-aging activity in human skin, with the synergism established between some specific components of the EOs, mainly sesquiterpenes, enhancing the anti-aging properties of the formulations [150]. This is because sesquiterpenes present a significant inhibitory activity of different enzymes related to the skin aging, e.g., collagenase, elastase, hyaluronidase, and tyrosinase. Furthermore, it was reported that mixtures containing both essential oils present a stronger anti-aging effect than each individual one. On the other hand, the anti-aging activity of the formulations is also correlated to the ability for free radical scavenging as was demonstrated by Tu and Tawata [151] using EOs from two different varieties of Alpinia zerumbet. They found that the variety providing the essential oil with the highest concentration of antioxidant molecules, such as monoterpenes, leads to a stronger antioxidant effect against UV-induced damage of the skin. This is possible because monoterpenes produce a significant inhibition of the activity of the enzymes associated with the skin aging (collagenase, elastase, hyaluronidase, and tyrosinase), and of the melanogenesis. The latter suggests that EOs may be also used in skin-whitening materials. Lemon essential oil is considered as one of the most effective substances for slowing down the aging process because it presents a high vitamin C content, making it an essential component in many cosmetic formulation for skin care [152]. 
Table 3. Some potential applications of essential oils in skin care.

\begin{tabular}{|c|c|c|c|}
\hline Application & Essential Oil & Plant & References \\
\hline \multirow{5}{*}{ Antiacne } & citronella grass & Cymbopogon nardus & [142] \\
\hline & palmarosa & Cymbopogan martini & [144] \\
\hline & Artemisin & Artemisia annua & [143] \\
\hline & Geranium & Geranium rotundifolium & [148] \\
\hline & n.a. ${ }^{1}$ & Nigella sativa & [146] \\
\hline \multirow{13}{*}{ Skin aging } & geranium & Geranium rotundifolium & [148] \\
\hline & patchouli & Pogostemon cablin & [149] \\
\hline & nutmeg & Myristica fragrans & [149] \\
\hline & citronella & Cymbopogon nardus & [149] \\
\hline & Clove & Syzygium aromaticum & [149] \\
\hline & n.a. ${ }^{1}$ & Pluchea dioscoridis & [150] \\
\hline & n.a. ${ }^{1}$ & Erigeron bonariensis & [150] \\
\hline & shell ginger & Alpinia zerumbet & [151] \\
\hline & lemon & Citrus lemon & [152] \\
\hline & lavender & Lavandula officinalis & [153] \\
\hline & Sage & Salvia officinalis & [153] \\
\hline & rosehip & Rosa canina & [154] \\
\hline & carrot & Daucus carota & [57] \\
\hline \multirow{8}{*}{ Anti-wrinkle } & patchouli & Pogostemon cablin & {$[149,155]$} \\
\hline & nutmeg & Myristica fragrans & [149] \\
\hline & citronella & Cymbopogon nardus & [149] \\
\hline & Clove & Syzygium aromaticum & [149] \\
\hline & ylang-ylang & Cananga odorata & [156] \\
\hline & carrot & Daucus carota & [57] \\
\hline & neroli & Citrus sinensis & [157] \\
\hline & rosehip & Rosa canina & [154] \\
\hline \multirow{4}{*}{ Moisturizer } & n.a. ${ }^{1}$ & Hypericum perforatum & [117] \\
\hline & rosehip & Rosa canina & [158-160] \\
\hline & sandalwood & Santalum spicatum & [161] \\
\hline & chamomile & Matricaria chamomilla & [162] \\
\hline \multirow{3}{*}{ Oily skin } & geranium & Geranium rotundifolium & [141] \\
\hline & neroli & Citrus sinensis & [157] \\
\hline & ylang-ylang & Cananga odorata & [156] \\
\hline
\end{tabular}

${ }^{1}$ There is no defined a name for the specific essential oil.

The skin aging process is also related to the mechanical properties of the skin barrier, which is closely correlated to the homeostatic equilibrium. Therefore, any alteration of the normal mechanical barrier function of the skin may alter its normal homeostatic equilibrium. This latter can be modulated by the application of EOs as was demonstrated by de Andrade et al. [153]. They found that the application of EOs of lavender and sage at a reduced dose (in the range $5-10 \% w / w$ ) increases the thickness of the skin hydration layer, with the penetration of the EOs through the skin remaining very limited. This latter point should be considered a very important aspect associated with the tox- 
icological profile of formulations containing EOs or their individual components. The potential application of other EOs as moisturizing agents has been also reported, including Hypericum perforatum, rosehip seed oil from Rosa canina, sandalwood essential oil, or chamomile essential oil $[117,158,161,162]$. The moisturizing role in the latter essential oil is ascribed to its high content in azulene $[141,162]$. However, rose essential oil has been reported as the most powerful substance for maintaining the moisture loss from skin, becoming an essential component of formulations for keeping skin hydration, lightening dark spots, eliminating pimples, and reducing fine lines and wrinkles $[159,160]$. The latter effect has been also ascribed to patchouli and ylang-ylang essential oil, with the later contributing also to tissue regeneration $[155,156]$.

Moreover, rosehip seed oil was found to reduce wrinkles, increasing the skin's elasticity. On the other hand, the presence of antioxidant compounds in carrot seed oil helps in the reduction of UV-induced damage, and, consequently, a reduction in the aging of the skin [154]. Its strong antioxidant character is due to its ability to stimulate the regeneration of skin cells, thus maintaining smooth skin, being one of the best choices for anti-aging purposes. This is commonly associated with the high content of flavonoids and carotenoids that contribute to the prevention of the inflammation, repairing the damaged skin by stimulating the production of vitamins A and E. Furthermore, carrot seed oil provides protection against the damages to the skin induced by sun and other free radicals, and helps in the reduction of scars and wrinkles in mature skin [57]. Neroli essential oil can be also exploited for reducing wrinkles due to their recognized impact on the skin's elasticity $[156,157]$.

The physiological balance between the sebum and sweat may become a very important health and aesthetic problem. However, the application of formulations containing EOs may help in the partial mitigation of this type of problem. Geranium essential oil as result of its alkaline character can contribute to reducing the excess oil from the skin which block pores, and therefore contribute to maintaining the natural sebum balance [141]. Similarly, the presence of citral in neroli essential oil can contribute to maintaining the oil balance of the skin without drying the skin [157]. The control of the oily secretions can also be performed using ylang-ylang essential oil [156], but in particular by using rosemary essential oil which contains a high ester content facilitating the control of excess sebum [108].

In summary, EOs and EOCs have been applied in novel skin care formulations for their many properties, including their beneficial effects on acne, pimples, eczema and psoriasis, and their capacity for offering a healthy, glowing, and younger aspect to the skin.

\subsection{Other Possible Applications of EOs and EOCs in Cosmetics and Toiletries}

The use of EOs and EOCs in the cosmetic industry is currently extended beyond their use in the formulation of fragrances, and their inclusion in traditional cosmetics and toiletries for hair and skin care, and hence there are some examples available related to the application of EOs for other cosmetic purposes [84].

Essential oils may be exploited in the preparation of sunscreen formulation because they can absorb most of the UV radiations (in the wavelength range $290-400 \mathrm{~nm}$ ), preventing photo-aging, sunburn, skin wrinkles, and other skin damages [163]. Mishra et al. [120] studied in vitro protection upon UV radiation exposure of formulations containing Calendula oficinalis essential oil, and found that the prepared formulations present good properties for protecting skin against sunlight exposure, with the Sun Protection Factor (SPF) evaluated by spectroscopic measurements, according to the protocol developed by Mansur et al. [164], being within the limits expected for sunscreen products. Furthermore, the combination of the sunscreen properties of the essential oil with its antioxidant character leads to a synergistic effect which enhances the photoprotective character of the formulations [163]. Similarly, Kaur and Saraf [165] evaluated the ability of different volatile and non-volatile oils for adsorbing UV radiation to estimate their SPF, and found that nonvolatile oils presents generally higher values of SPF. However, the use of peppermint oil allows preparing sunscreen formulations with a similar SPF value to those corresponding 
to the non-volatile oil with the best performance. This may be considered an important aspect in the choice of oils and fragrances in the design of sunscreen products. Furthermore, the correct choice of the oil becomes a critical aspects because the characteristics of the oils control the production of a uniform sunscreen film on the skin with a long duration, and contribute to the protection of the skin against drying by wind and sun actions.

Kale et al. [166] evaluated a sunscreen cream containing essential oil from Ocimum basilicum in a relatively low concentration $(0.6 \% w / w)$ and found that it's in vitro behavior was only slightly worse than that obtained for common products used for protection against sunlight. This suggests that the use of the above essential oil may be a good alternative for the preparation of sunscreen products. Patchouli essential oil was also found as a very effective alternative for protecting against the harmful UV radiation, which is mainly ascribed to the role of their antioxidant compounds (patchouli alcohol, guaiene, isocaryophyllene, caryophyllene, and selinen) [154].

It should be noted that in many cases the sunscreen activity of essential oils is coupled to other benefits for skin health. However, this is not the case for the essential oil of Oncosiphon suffruticosum, which presents a good protection against UV radiation, blocking around the $57 \%$ of the incident UV radiation, however presents low tyrosinase inhibitory activity and low to moderate antibacterial and antioxidant activity. This latter characteristic is very surprising due to the antiaging performance and the protection against bacterial-induced diseases of different essential oils containing similar main components to Oncosiphon suffruticosum (camphor, filifolone, chrysanthenone, 1,8-cineole, and terpinen-4-ol) [167].

The introduction of EOs and their individual components in formulations of lipsticks is also becoming very popular in recent years [168]. Afandi et al. [169] introduced essential oil obtained from Hylocereus polyrhizus, demonstrating their power for enhancing the antimicrobial activity of the lipstick formulation. Furthermore, EO and EOCs are also used in lipstick formulations to provide a specific flavor to the product [170], or as dispersant medium for different colorants [171].

\section{EOs and EOCs as Preservatives in Cosmetic Products}

The manufacturing of cosmetic products requires the use of several preservatives in the smallest possible concentrations for ensuring the protection of formulations from microorganism contaminations. However, synthetic preservatives are many times sources of allergies and irritant contact dermatitis [117]. This makes necessary to manufacture formulations without any added preservative. This requirement may be partially accomplished by adding EOs which can be used simultaneously as active ingredients and preservatives, allowing the preparation of self-preserving or preservative-free formulations [153]. Therefore, EOs and their individual components can be considered as costeffective preserving substances which may contribute to obtained products with enhanced dermocosmetic properties.

EOs from different sources, e.g., lavender (Lavandula angustifolia), thyme (Thymus vulgaris), peppermint (Mentha piperita), cajuput (Melaleuca cajuputi), cinnamon (Cinnamomum zeylanicum), clove (Syzygium aromaticum), eucalyptus (Eucalyptus globulus), sage (Salvia officinalis), and tea tree (Melaleuca alternifolia) are associated with antimicrobial activity. This is commonly associated with their high concentration on phenolic, aromatic, or alcoholic components, which present a strong bioactivity against pathogenic microorganisms [139].

Gontar et al. [172] explored the use of EOs from different sources, namely Monarda citriodora, Monarda didyma, and Monarda media, as preservatives for cosmetic formulations, and found that their effectiveness against bacteria and fungi was correlated to the relative content of specific EOCs. In particular, the increase of the content of p-cymene in the essential oil allows the inhibition of the emergence of microorganisms as evidenced their limited proliferation in formulations containing Monarda media. However, the EOs of Monarda citriodora and Monarda didyma can be only included in the formulation for reducing the amount of synthetic preservative compounds since they are not effective for inhibiting 
microorganism proliferation. The above results suggest that the preservative role is related to the presence of specific essential oil components.

The study of the different activity of EOs as preservative of cosmetic products was extended by Muyima et al. [137]. They explored the antimicrobial role of up to four EOs from different sources, namely Artemisia afra, Pteronia incana, Lavandula officinalis, and Rosmarinus officinalis oils, against different microorganisms (fungi and bacteria), and found that the four oils may be exploited as preservatives of creams. However, slight variations on the antimicrobial properties were reported due to the different susceptibility of the tested organisms to some specific components of the EOs, which leads to a better performance of the Artemisia afra as a preservative. Furthermore, Muyima et al. [137] also found that fungi are more susceptible than bacteria to the preservation with EOs in agreement with the results previously reported by Mangena and Muyima [173].

The above discussion evidenced the power of EOs and EOCs in the preservation of cosmetics product. However, their use may sometimes be discouraged due to a series of important drawbacks [174]: (i) their high organism specificity requires a careful analysis of the most suitable composition for preserving against specific microorganisms; (ii) EOs and EOCs can induce the emergence of allergies; (iii) their strong odors may be inappropriate for some specific cosmetic applications, and (iv) the reduction of the antimicrobial action as result of their volatility and lipophilicity.

\section{Encapsulation of EOs and EOCs in Cosmetic}

It was stated above that the use of EOs and EOCs in the formulation of products present several drawbacks, which make difficult their manipulation and handling due to their volatility, limited solubility in water, and thermal and chemical lability (most of these substances undergo fast oxidation process upon exposure to the environment). These problems may be partially overcome by solubilizing, encapsulating and/or protecting the active molecules by using different type of nanocarriers, e.g., soft nanoparticles (polymeric or solid lipid), hard nanomaterials, cyclodextrins, liposomes or emulsions [175-186]. The use of nanocarriers may help on preparing formulations containing the active compounds (EOs and EOCs) within a well-controlled container, which can contribute to the enhancement of their stability and availability. Furthermore, this makes possible a controlled release of the active molecules, reducing the losses during processing and storage [187-193]. On the other hand, the use of strategies for protecting the EOs and EOCs may enhance their molecular stability, retarding their crystallization, and minimizing their chemical reactivity (volatility, photodegradation, hydrolysis, oxidation, thermal decomposition or isomerization) [194-197]. Therefore, the introduction of a barrier between the essential oils, or their individual components, and the environment through encapsulation processes may be a very interesting alternative for exploiting this type of materials in cosmetic industry [12].

The development of encapsulation systems must consider both the active ingredients and the carrier materials, as well as the release mechanism and final application of the obtained formulation [13]. The choice of the most suitable carrier material is critical because it defines most of the physico-chemical characteristic of the capsule, their stability and release characteristics [198]. On the other side, the encapsulation process is selected in such a way that can be reproducible, fast, effective, and scalable to an industrial process. Furthermore, the nature of the encapsulated compounds as well as their final application plays a very important role on the design of the encapsulation process [199-203].

There are numerous available methodologies for the encapsulation of active molecules, and this number does not stop to increase with companies introducing continuously novel encapsulation approaches for improving the efficiency of their formulations [15]. Thus, even though there are a broad range of available techniques for encapsulation purposes, they can be commonly classified in three groups depending of their main characteristics: (i) chemical; (ii) physico-chemical, and (iii) physico-mechanical. Table 4 includes some examples of methodologies classified in terms of their respective categories. It should be noted that 
the aim of this work is far from providing a description of the different methodologies used for the encapsulation of actives, and the reading of references [15,204-207] is strongly recommended for deepen on technical aspects of such processes.

The encapsulation of EOs and EOCs is becoming extremely attractive for cosmetic industry, and some examples of this interest are reported in the literature, especially focused in enlarging the duration of the odor associated with essential oil derived fragrances. Park et al. [208] demonstrated the possibility for using encapsulation of lemon essential oil in microcapsules of urea-formaldehyde for preserving the duration of its fragrance upon their incorporation into cosmetic products. A similar aim was pursued by Weinbreck et al. [209] using a complex coacervation method for encapsulating essential oils of lemon and orange. The coacervation approach was also chosen by Martins et al. [210] for encapsulating thyme oil. Gumi et al. [211] chose the phase inversion for precipitation to enhance the preservation of vanillin. The use of a very simple emulsification methodology was used by Lucia et al. [21] for preparing pediculicidal lotions with different EOCs. The emulsification was also chosen by Shahtalebi et al. [212] for preparing a shampoo containing encapsulated eugenol, an essential oil component of the clove oil, for hair conditioning. This formulation showed good conditioning and grooming properties, contributing to the hair reparation. On the other hand, Anchisi et al. [213], seeking more sustainable formulations, designed chitosan capsules containing Mentha piperita essential oil. This type of formulations aws found to protect the properties of the essential oil for more than six months.

Table 4. Summary of methodologies commonly exploited in the encapsulation of active compounds.

\begin{tabular}{|c|c|c|c|}
\hline Category & Methodology & Examples of Encapsulated EOs & References \\
\hline \multirow{3}{*}{ Chemical } & interfacial polymerization & osmanthus & [214] \\
\hline & emulsion polymerization & jasmine & [215] \\
\hline & suspension polymerization & canola & [216] \\
\hline \multirow{8}{*}{ Physico-chemical } & simple and complex coacervation (phase separation) & sweet orange, thyme & {$[145,210]$} \\
\hline & precipitation & sweet orange and bergamot & [109] \\
\hline & emulsification & lavandin & [217] \\
\hline & solvent evaporation/extraction & babchi & [218] \\
\hline & & lemongrass, citronella, basil, & \\
\hline & sol/gel encapsulation & $\begin{array}{l}\text { rosemary, eucalyptus, tea tree, } \\
\text { lavender, clove and cinnamon }\end{array}$ & [219] \\
\hline & supercritical fluid assisted encapsulation & lime & [220] \\
\hline & Layer-by-Layer & garlic, thyme & {$[221,222]$} \\
\hline \multirow{8}{*}{ Physical-mechanical } & air suspension method & nutmeg & [223] \\
\hline & pan coating & cinnamon & [224] \\
\hline & spray drying & orange & [225] \\
\hline & spray chilling/spray cooling & oregano & [226] \\
\hline & fluid bed coating & orange & [227] \\
\hline & co-extrusion & rosemary & [228] \\
\hline & spinning-disk & rosemary & [191] \\
\hline & melt solidification & lavandin & [229] \\
\hline
\end{tabular}

\section{Toxicity and Allergenic Character of EOs and EOCs in Cosmetics and Toiletries}

EOs and EOCs are currently widespread in cosmetic products and are widely considered as safe products. However, there are some examples of adverse effects (e.g, allergies and chronic toxicity in human cells), that make it necessary to take care in their application, and in particular, on their dosage for minimizing the potential risks associated with the exposure to this type of substances [58,230-232]. This requires consideration of the dose, composition, dilution, frequency of use, and application [233].

It is true that most of the potential safety issues associated with the use of EOs is the results of poor quality or low grade of the raw botanical extract. This can induce skin irritation, allergic reactions, or even hepatotoxic upon a prolonged exposure. On the 
other side, there are some EOs that are stronger photosensitizers, which may increase the damages on the skin upon exposure to sunlight. Therefore, it is recommended to perform a detailed analysis of the Material Safety Data Sheet before the inclusion of a specific essential oil in cosmetics or toiletries [234].

There are some EOs and EOCs that present higher tendency to induce potential adverse reactions than others, and in particular there are some EOCs that may be considered as very powerful allergen. Furthermore, the contamination or adulteration of EOs and EOCs can also influence their allergenic power. On the other hand, the oxidation process of some EOCs, e.g., (+)-limonene, $\delta$-3-carene and $\alpha$-pinene, makes them much more reactive, leading to stronger reactivity [11]. Nevertheless, it should be noted that the oxidation of the EOCs are not always signature of an increase of their allergenic risk [27].

The most common adverse reaction associated with the use of EOs in cosmetic products appears upon their contact with the skin, e.g., dermal reactions, contact dermatitis, phototoxicity/photosensitivity reactions by sun exposure [235]. This type of reactions are commonly associated to the presence of specific EOCs, e.g., cinnamic alcohol, aldehyde, eugenol, and baptapene [116]. Furthermore, the use of high concentrations of EOs in cosmetic products increases the risks, and even it can trigger dermal sensitization phenomena [236]. Despite the potential allergenic character of EOs and EOs compounds, it should be noted that the comparison of the number of allergic reactions upon application of these substances with their widely application makes possible to consider the use of EOs and EOCs in cosmetic products as safe except for a small population of susceptible individuals [24]. However, it is important to take into account the possible adverse reactions when extending the use of EOs in cosmetics and toiletries. Table 5 summarizes some examples of allergenic reactions associated with the essential oils in cosmetics and toiletries.

Table 5. Summary of essential oils associated with the emergence of allergic reactions upon contact with skin and mucosa.

\begin{tabular}{cccc}
\hline Essential Oil & Main Allergenic Component & Incidence (Cases per 10,000 Habitants) & References \\
\hline Peppermint & limone & 50 & {$[237-239]$} \\
Tea tree & 1,8 -cineole & 100 & {$[239]$} \\
Eucalyptus & 1,8 -cineole & $24-150$ & {$[240,241]$} \\
Lavender & linalyl acetate (oxidation subproducts) & 1000 & {$[242]$} \\
Ylang-ylang & isoeugeno & 1400 & {$[243]$} \\
\hline
\end{tabular}

A report of the North American Contact Dermatitis Group has estimated that almost $1 \%$ of the population is susceptible to allergic response to tea tree oil (Melaleuca alternifolia). This susceptibility is associated with the relative high content of 1,8-cineole [239], which is a main component in relation to the beneficial antimicrobial effects associated with the use of tea tree oil. Other important allergenic essential oil is peppermint oil (Mentha piperita), which can lead to pruritus and inflammation. This is commonly associated with the high content of menthol, menthone, carvone, pulegone, and limonene, which the latter being currently considered an emerging allergen [237]. Furthermore, peppermint oil can induce allergic contact dermatitis upon topical application with an incidence close to $0.5 \%$ of the population $[238,239]$.

Lavender oil is also associated with the emergence of allergic reaction upon the application of cosmetics and toiletries incorporating it within its composition [244]. Furthermore, the incidence of the allergic contact dermatitis associated with lavender oil is relatively high (above $10 \%$ of the population) [245]. This is associated with the two main components of the lavender oil (linalyl acetate and linalool) which are weak allergens and sensitizers in pure form [246]. However, the allergenic power of lavender oil is enhanced upon linalyl acetate oxidation [242]. Eucalyptus oil is also associated with the emergence of allergic contact dermatitis as result of its high content in 1,8-cineole [240,241]. On the other hand, the presence of isoeugenol is the responsible of sensitization in ylang-ylang oil [243]. 


\section{Conclusions}

Essential oils (EOs) and their individual components (EOCs) are a family of substances with increasing interest for cosmetic industry. This is the result of their many biological properties, including antibacterial, antifungal, anti-inflammatory or antioxidant one, which can be exploited for supporting health, beauty, and wellness. This has pushed the essential oil usage range beyond the fragrance world, and nowadays they are widespread in products for hair and skin care as well as natural preservatives in many formulations, leading to an almost endless lists of uses which is continuously growing. Therefore, essential oils have become essential components contributing to the optimal balance of the physical wellness. However, the important role of EOs and EOCs in the current development of cosmetic industry towards greener and eco-sustainable products cannot mask the safety issues associated with the use of EOs and EOCs in the final products, which makes it necessary to take care on their dosage. Therefore, it is clear that EOs and EOCs are a very important source of bioactive molecules for cosmetic industry, even though it is mandatory a careful analysis of their application conditions. On the other hand, the use of essential oil in cosmetics and toiletries is not only an advantage from the perspective of the cosmetic benefits associated with the products and their role as preservatives, playing also a very important role in the marketing image of commercial products. This makes necessary to push the research towards a better understanding of the most fundamental bases underlying their biological performance and their potential toxicological aspects to open new avenues in the development of essential oil based cosmetic products. Therefore, considering the interest of cosmetic industry for replacing traditional actives for greener bioactive ingredients, it is necessary to perform more systematic tests evaluating the real performance of essential oils in final formulations.

Author Contributions: E.G. and A.L. have contributed equally to the elaboration of this work. All authors have read and agreed to the published version of the manuscript.

Funding: This work was funded by MICINN under grant PID2019-106557GB-C21 and by E.U. on the framework of the European Innovative Training Network-Marie Sklodowska-Curie Action NanoPaint (grant agreement 955612).

Institutional Review Board Statement: Not applicable.

Informed Consent Statement: Not applicable.

Data Availability Statement: This work does not present any associated data.

Conflicts of Interest: The authors declare no conflict of interest. The funders had no role in the design of the study; in the collection, analyses, or interpretation of data; in the writing of the manuscript, or in the decision to publish the results.

\section{References}

1. Mahesh, S.K.; Fathima, J.; Veena, V.G. Cosmetic Potential of Natural Products: Industrial Applications. In Natural Bio-Active Compounds: Volume 2: Chemistry, Pharmacology and Health Care Practices; Swamy, M.K., Akhtar, M.S., Eds.; Springer: Singapore, 2019; pp. 215-250.

2. Morea, D.; Fortunati, S.; Martiniello, L. Circular economy and corporate social responsibility: Towards an integrated strategic approach in the multinational cosmetics industry. J. Clean. Prod. 2021, 315, 128232. [CrossRef]

3. Sharma, M.; Trivedi, P.; Deka, J. A paradigm shift in consumer behaviour towards green cosmetics: An empirical study. Int. J. Green Econ. 2021, 15, 1-19. [CrossRef]

4. Luengo, G.S.; Fameau, A.-L.; Léonforte, F.; Greaves, A.J. Surface science of cosmetic substrates, cleansing actives and formulations. Adv. Colloid Interface Sci. 2021, 290, 102383. [CrossRef]

5. Llamas, S.; Guzmán, E.; Ortega, F.; Baghdadli, N.; Cazeneuve, C.; Rubio, R.G.; Luengo, G.S. Adsorption of polyelectrolytes and polyelectrolytes-surfactant mixtures at surfaces: A physico-chemical approach to a cosmetic challenge. Adv. Colloid Interface Sci. 2015, 222, 461-487. [CrossRef]

6. Fernández-Peña, L.; Guzmán, E.; Leonforte, F.; Serrano-Pueyo, A.; Regulski, K.; Tournier-Couturier, L.; Ortega, F.; Rubio, R.G.; Luengo, G.S. Effect of molecular structure of eco-friendly glycolipid biosurfactants on the adsorption of hair-care conditioning polymers. Colloids Surf. B 2020, 185, 110578. [CrossRef] 
7. Hernández-Rivas, M.; Guzmán, E.; Fernández-Peña, L.; Akanno, A.; Greaves, A.; Léonforte, F.; Ortega, F.; G Rubio, R.; Luengo, G.S. Deposition of Synthetic and Bio-Based Polycations onto Negatively Charged Solid Surfaces: Effect of the Polymer Cationicity, Ionic Strength, and the Addition of an Anionic Surfactant. Colloids Interfaces 2020, 4, 33. [CrossRef]

8. Bowman, D.M.; van Calster, G.; Friedrichs, S. Nanomaterials and regulation of cosmetics. Nat. Nanotechnol. 2010, 5, 92. [CrossRef] [PubMed]

9. Kentin, E.; Kaarto, H. An EU ban on microplastics in cosmetic products and the right to regulate. Rev. Eur. Comp. Int. Environ. Law 2018, 27, 254-266. [CrossRef]

10. Henkler, F.; Tralau, T.; Tentschert, J.; Kneuer, C.; Haase, A.; Platzek, T.; Luch, A.; Götz, M.E. Risk assessment of nanomaterials in cosmetics: A European union perspective. Arch. Toxicol. 2012, 86, 1641-1646. [CrossRef]

11. Bakkali, F.; Averbeck, S.; Averbeck, D.; Idaomar, M. Biological effects of essential oils-A review. Food Chem. Toxicol. 2008, 46, 446-475. [CrossRef]

12. de Barros Fernandes, R.V.; Marques, G.R.; Borges, S.V.; Botrel, D.A. Effect of solids content and oil load on the microencapsulation process of rosemary essential oil. Ind. Crops Prod. 2014, 58, 173-181. [CrossRef]

13. Nazzaro, F.; Orlando, P.; Fratianni, F.; Coppola, R. Microencapsulation in food science and biotechnology. Curr. Opin. Biotechnol. 2012, 23, 182-186. [CrossRef]

14. Juliano, C.; Magrini, G.A. Cosmetic Functional Ingredients from Botanical Sources for Anti-Pollution Skincare Products. Cosmetics 2018, 5, 19. [CrossRef]

15. Carvalho, I.T.; Estevinho, B.N.; Santos, L. Application of microencapsulated essential oils in cosmetic and personal healthcare products-A review. Int. J. Cosmet. Sci. 2016, 38, 109-119. [CrossRef] [PubMed]

16. Lucia, A.; Guzmán, E. Emulsions containing essential oils, their components or volatile semiochemicals as promising tools for insect pest and pathogen management. Adv. Colloid Interface Sci. 2021, 287, 102330. [CrossRef] [PubMed]

17. Sotelo, C.G.; Blanco, M.; Ramos, P.; Vázquez, J.A.; Perez-Martin, R.I. Sustainable Sources from Aquatic Organisms for Cosmeceuticals Ingredients. Cosmetics 2021, 8, 48. [CrossRef]

18. Martins, A.; Vieira, H.; Gaspar, H.; Santos, S. Marketed Marine Natural Products in the Pharmaceutical and Cosmeceutical Industries: Tips for Success. Mar. Drugs 2014, 12, 1066-1101. [CrossRef]

19. Varvaresou, A.; Iakovou, K. Biosurfactants in cosmetics and biopharmaceuticals. Lett. Appl. Microbiol. 2015, 61, 214-223. [CrossRef]

20. Moldes, A.B.; Rodríguez-López, L.; Rincón-Fontán, M.; López-Prieto, A.; Vecino, X.; Cruz, J.M. Synthetic and Bio-Derived Surfactants Versus Microbial Biosurfactants in the Cosmetic Industry: An Overview. Int. J. Mol. Sci. 2021, 22, 2371. [CrossRef]

21. Lucia, A.; Toloza, A.C.; Guzmán, E.; Ortega, F.; Rubio, R.G. Novel polymeric micelles for insect pest control: Encapsulation of essential oil monoterpenes inside a triblock copolymer shell for head lice control. PeerJ 2017, 5, e3171. [CrossRef]

22. Wang, H.-M.D.; Chen, C.-C.; Huynh, P.; Chang, J.-S. Exploring the potential of using algae in cosmetics. Bioresour. Technol. 2015, 184, 355-362. [CrossRef] [PubMed]

23. Sharmeen, J.B.; Mahomoodally, F.M.; Zengin, G.; Maggi, F. Essential Oils as Natural Sources of Fragrance Compounds for Cosmetics and Cosmeceuticals. Molecules 2021, 26, 666. [CrossRef] [PubMed]

24. Sarkic, A.; Stappen, I. Essential Oils and Their Single Compounds in Cosmetics-A Critical Review. Cosmetics $2018,5,11$. [CrossRef]

25. Lubbe, A.; Verpoorte, R. Cultivation of medicinal and aromatic plants for specialty industrial materials. Ind. Crops Prod. 2011, 34, 785-801. [CrossRef]

26. Raut, J.S.; Karuppayil, S.M. A status review on the medicinal properties of essential oils. Ind. Crops Prod. 2014, 62, 250-264. [CrossRef]

27. De Groot, A.C.; Schmidt, E. Essential Oils: Contact Allergy and Chemical Composition; CRC Press: Boca Raton, FL, USA, 2016.

28. Burt, S. Essential oils: Their antibacterial properties and potential applications in foods-A review. Int. J. Food Microbiol. 2004, 94, 223-253. [CrossRef]

29. Ni, Z.-J.; Wang, X.; Shen, Y.; Thakur, K.; Han, J.; Zhang, J.-G.; Hu, F.; Wei, Z.-J. Recent updates on the chemistry, bioactivities, mode of action, and industrial applications of plant essential oils. Trends Food Sci. Technol. 2021, 110, 78-89. [CrossRef]

30. Dhifi, W.; Bellili, S.; Jazi, S.; Bahloul, N.; Mnif, W. Essential Oils' Chemical Characterization and Investigation of Some Biological Activities: A Critical Review. Medicines 2016, 3, 25. [CrossRef]

31. da Silva, B.D.; Bernardes, P.C.; Pinheiro, P.F.; Fantuzzi, E.; Roberto, C.D. Chemical composition, extraction sources and action mechanisms of essential oils: Natural preservative and limitations of use in meat products. Meat Sci. 2021, 176, 108463. [CrossRef]

32. Aljaafari, M.N.; AlAli, A.O.; Baqais, L.; Alqubaisy, M.; AlAli, M.; Molouki, A.; Ong-Abdullah, J.; Abushelaibi, A.; Lai, K.-S.; Lim, S.-H.E. An Overview of the Potential Therapeutic Applications of Essential Oils. Molecules 2021, 26, 628. [CrossRef]

33. Figueiredo, A.C.; Barroso, J.G.; Pedro, L.G.; Scheffer, J.J.C. Factors affecting secondary metabolite production in plants: Volatile components and essential oils. Flavour Fragr. J. 2008, 23, 213-226. [CrossRef]

34. Pavela, R. Essential oils for the development of eco-friendly mosquito larvicides: A review. Ind. Crops Prod. 2015, 76, 174-187. [CrossRef]

35. Ngahang Kamte, S.L.; Ranjbarian, F.; Cianfaglione, K.; Sut, S.; Dall'Acqua, S.; Bruno, M.; Afshar, F.H.; Iannarelli, R.; Benelli, G.; Cappellacci, L.; et al. Identification of highly effective antitrypanosomal compounds in essential oils from the Apiaceae family. Ecotox. Environ. Saf. 2018, 156, 154-165. [CrossRef] 
36. Quassinti, L.; Bramucci, M.; Lupidi, G.; Barboni, L.; Ricciutelli, M.; Sagratini, G.; Papa, F.; Caprioli, G.; Petrelli, D.; Vitali, L.A.; et al. In vitro biological activity of essential oils and isolated furanosesquiterpenes from the neglected vegetable Smyrnium olusatrum L. (Apiaceae). Food Chem. 2013, 138, 808-813. [CrossRef] [PubMed]

37. Jamalova, D.N.; Gad, H.A.; Akramov, D.K.; Tojibaev, K.S.; Musayeib, N.M.A.; Ashour, M.L.; Mamadalieva, N.Z. Discrimination of the Essential Oils Obtained from Four Apiaceae Species Using Multivariate Analysis Based on the Chemical Compositions and Their Biological Activity. Plants 2021, 10, 1529. [CrossRef] [PubMed]

38. Rustaiyan, A.; Faridchehr, A. Constituents and biological activities of selected genera of the Iranian Asteraceae family. J. Herbal. Med. 2021, 25, 100405. [CrossRef]

39. Razafiarimanga, Z.N.; Judicael, L.; Randriamampianina; Randrianarivo, H.R.; Sadam, S.M.b.; Rakoto, D.A.D.; Jeannoda, V.L. Chemical composition and antimicrobial properties of the essential oil from the leaves of Helichrysum ibityense R.Vig. \& Humbert (Asteraceae). GSC Biol. Pharm. Sci. 2021, 15, 143-153. [CrossRef]

40. Shanaida, M.; Hudz, N.; Białoń, M.; Kryvtsowa, M.; Svydenko, L.; Filipska, A.; Paweł Wieczorek, P. Chromatographic profiles and antimicrobial activity of the essential oils obtained from some species and cultivars of the Mentheae tribe (Lamiaceae). Saudi J. Biol. Sci. 2021, 28, 6145-6152. [CrossRef]

41. Ghavam, M.; Manconi, M.; Manca, M.L.; Bacchetta, G. Extraction of essential oil from Dracocephalum kotschyi Boiss. (Lamiaceae), identification of two active compounds and evaluation of the antimicrobial properties. J. Ethnopharm. 2021, 267, 113513. [CrossRef] [PubMed]

42. Damasceno, C.S.B.; Fabri Higaki, N.T.; Dias, J.d.F.G.; Miguel, M.D.; Miguel, O.G. Chemical Composition and Biological Activities of Essential Oils in the Family Lauraceae: A Systematic Review of the Literature. Planta Med. 2019, 85, 1054-1072. [CrossRef]

43. Salleh, W.M.N.H.W.; Ahmad, F.; Yen, K.H. Chemical compositions and biological activities of the essential oils of Beilschmiedia madang Blume (Lauraceae). Arch. Pharm. Res. 2015, 38, 485-493. [CrossRef] [PubMed]

44. Caputo, L.; Smeriglio, A.; Trombetta, D.; Cornara, L.; Trevena, G.; Valussi, M.; Fratianni, F.; De Feo, V.; Nazzaro, F. Chemical Composition and Biological Activities of the Essential Oils of Leptospermum petersonii and Eucalyptus gunnii. Front. Microbiol. 2020, 11, 409. [CrossRef]

45. Lobine, D.; Pairyanen, B.; Zengin, G.; Yılmaz, M.A.; Ouelbani, R.; Bensari, S.; Ak, G.; Abdallah, H.H.; Imran, M.; Mahomoodally, M.F. Chemical Composition and Pharmacological Evaluation and of Toddalia asiatica (Rutaceae) Extracts and Essential Oil by in Vitro and in Silico Approaches. Chem. Biodivers. 2021, 18, e2000999. [CrossRef]

46. Silva, F.B.D.; Santos, N.O.D.; Pascon, R.C.; Vallim, M.A.; Figueiredo, C.R.; Martins, R.C.C.; Sartorelli, P. Chemical Composition and In Vitro Cytotoxic and Antimicrobial Activities of the Essential Oil from Leaves of Zanthoxylum monogynum St. Hill (Rutaceae). Medicines 2017, 4, 31. [CrossRef] [PubMed]

47. Benelli, G.; Pavela, R.; Petrelli, R.; Cappellacci, L.; Canale, A.; Senthil-Nathan, S.; Maggi, F. Not just popular spices! Essential oils from Cuminum cyminum and Pimpinella anisum are toxic to insect pests and vectors without affecting non-target invertebrates. Ind. Crops Prod. 2018, 124, 236-243. [CrossRef]

48. Pouresmaeil, M.; Sabzi, M.; Movafeghi, A.; Maggi, F. Exploring the bio-control efficacy of Artemisia fragrans essential oil on the perennial weed Convolvulus arvensis: Inhibitory effects on the photosynthetic machinery and induction of oxidative stress. Ind. Crops Prod. 2020, 155, 112785. [CrossRef]

49. Mann, J.; Davidson, R.S.; Hobbs, J.B.; Banthorpe, D.V.; Harborne, J.B. Natural Products: Their Chemistry and Biological Significance; Longman: London, UK, 1994.

50. Steward, D. The Chemistry of Essential Oils Made Simple; Care Publications: New York, NY, USA, 2005.

51. Turek, C.; Stintzing, F.C. Stability of Essential Oils: A Review. Compr. Rev. Food Sci. Food Saf. 2013, 12, 40-53. [CrossRef]

52. Senatore, F. Influence of harvesting time on yield and composition of the essential oil of a thyme (Thymus pulegioides L.) growing wild in Campania (Southern Italy). J. Agric. Food Chem. 1996, 44, 1327-1332. [CrossRef]

53. Pichersky, E.; Noel, J.P.; Dudareva, N. Biosynthesis of plant volatiles: Nature's diversity and ingenuity. Science 2006, 311, 808-811. [CrossRef]

54. Franz, C.M.; Novak, J. Sources of essential oils. In Handbook of Essential Oils. Science, Technology, and Applications; Başer, K.H., Buchbauer, G., Eds.; CRC Press: Boca Raton, FL, USA, 2010; pp. 39-81. [CrossRef]

55. Colquhoun, T.A.; Verdonk, J.C.; Schimmel, B.C.; Tieman, D.M.; Underwood, B.A.; Clark, D.G. Petunia floral volatile benzenoid/phenylpropanoid genes are regulated in a similar manner. Phytochemistry 2010, 71, 158-167. [CrossRef] [PubMed]

56. Luque de Castro, M.D.; Jiménez-Carmona, M.M.; Fernández-Pérez, V. Towards more rational techniques for the isolation of valuable essential oils from plants. Trends Anal. Chem. 1999, 18, 708-716. [CrossRef]

57. Singh, S.; Lohani, A.; Mishra, A.K.; Verma, A. Formulation and evaluation of carrot seed oil-based cosmetic emulsions. J. Cosmet. Laser Ther. 2019, 21, 99-107. [CrossRef] [PubMed]

58. Firenzuoli, F.; Jaitak, V.; Horvath, G.; Bassolé, I.H.; Setzer, W.N.; Gori, L. Essential oils: New perspectives in human health and wellness. Evid. Based Complement. Alternat. Med. 2014, 2014, 467363. [CrossRef]

59. Brophy, J.J.; Davies, N.W.; Southwell, I.A.; Stiff, I.A.; Williams, L.R. Gas chromatographic quality control for oil of Melaleuca terpinen-4-ol type (Australian tea tree). J. Agric. Food Chem. 1989, 37, 1330-1335. [CrossRef]

60. Bowman, J.M.; Braxton, M.S.; Churchill, M.A.; Hellie, J.D.; Starrett, S.J.; Causby, G.Y.; Ellis, D.J.; Ensley, S.D.; Maness, S.J.; Meyer, C.D.; et al. Extraction Method for the Isolation of Terpenes from Plant Tissue and Subsequent Determination by Gas Chromatography. Microchem. J. 1997, 56, 10-18. [CrossRef] 
61. Taverna, M.; Baillet, A.E.; Baylocq, D. Methodology for Evaluation of Compatibilities of Cosmetic Perfumes and Plastic Containers. J. Assoc. Off. Anal. Chem. 2020, 73, 206-210. [CrossRef]

62. Verma, R.K.; Uniyal, G.C.; Gupta, M.M. High performance liquid chromatography of poppy straw. Ind. J. Pharm. Sci. 1990, 52, 276-278.

63. Vernin, G.; Vernin, E.; Vernin, C.; Metzger, J.; Soliman, A. Extraction and gc-ms-specma data bank analysis of the aroma of Psidium guajava L. fruit from Egypt. Flavour Fragr. J. 1991, 6, 143-148. [CrossRef]

64. Chen, G.; Sun, F.; Wang, S.; Wang, W.; Dong, J.; Gao, F. Enhanced extraction of essential oil from Cinnamomum cassia bark by ultrasound assisted hydrodistillation. Chin. J. Chem. Eng. 2021, 36, 38-46. [CrossRef]

65. Gonzalez-Rivera, J.; Duce, C.; Campanella, B.; Bernazzani, L.; Ferrari, C.; Tanzini, E.; Onor, M.; Longo, I.; Ruiz, J.C.; Tinè, M.R.; et al. In situ microwave assisted extraction of clove buds to isolate essential oil, polyphenols, and lignocellulosic compounds. Ind. Crops Prod. 2021, 161, 113203. [CrossRef]

66. Dias, A.L.B.; de Aguiar, A.C.; Rostagno, M.A. Extraction of natural products using supercritical fluids and pressurized liquids assisted by ultrasound: Current status and trends. Ultrason. Sonochem. 2021, 74, 105584. [CrossRef]

67. Guzmán-Albores, J.M.; Bojórquez-Velázquez, E.; De León-Rodríguez, A.; Calva-Cruz, O.d.J.; Barba de la Rosa, A.P.; Ruíz-Valdiviezo, V.M. Comparison of Moringa oleifera oils extracted with supercritical fluids and hexane and characterization of seed storage proteins in defatted flour. Food Biosci. 2021, 40, 100830. [CrossRef]

68. Lefebvre, T.; Destandau, E.; Lesellier, E. Sequential extraction of carnosic acid, rosmarinic acid and pigments (carotenoids and chlorophylls) from Rosemary by online supercritical fluid extraction-supercritical fluid chromatography. J. Chromatogr. A 2021, 1639, 461709. [CrossRef]

69. Radivojac, A.; Bera, O.; Zeković, Z.; Teslić, N.; Mrkonjić, Ž.; Bursać Kovačević, D.; Putnik, P.; Pavlić, B. Extraction of Peppermint Essential Oils and Lipophilic Compounds: Assessment of Process Kinetics and Environmental Impacts with Multiple Techniques. Molecules 2021, 26, 2879. [CrossRef] [PubMed]

70. Patil, P.D.; Patil, S.P.; Kelkar, R.K.; Patil, N.P.; Pise, P.V.; Nadar, S.S. Enzyme-assisted supercritical fluid extraction: An integral approach to extract bioactive compounds. Trends Food Sci. Technol. 2021, 116, 357-369. [CrossRef]

71. Eyvazkhani, R.; Bahmanyar, H.; Mirdehghan Ashkezari, S.M.; Najafipour, I. Extraction of essential constituents from effluent of hydro-distillation of fennel and investigation of hydrodynamic parameters using a rotary disc column (RDC). Chem. Eng. Comm. 2021, 208, 993-1004. [CrossRef]

72. Mohammadi, M.; Khorshidian, N.; Gharibzahedi, S.M.T. The Extended Oxidative and Sensory Stability of Traditional Dairy-Based Oil with Steam-Distilled Essential Oils Extracted from the Bioactive-Rich Leaves of Ziziphora tenuior, Ferulago angulata, and Bunium persicum. J. Food Qual. 2021, 2021, 6613198. [CrossRef]

73. Salgueiro, L.; Martins, A.P.; Correia, H. Raw materials: The importance of quality and safety. A review. Flavour Fragr. J. 2010, 25, 253-271. [CrossRef]

74. Tisserand, R.; Young, R. Essential Oil Safety A Guide for Health Care Professionals; Elsevier: London, UK, $2014 ;$ pp. $187-482$.

75. Do, T.K.T.; Hadji-Minaglou, F.; Antoniotti, S.; Fernandez, X. Authenticity of essential oils. Trends Anal. Chem. 2015, 66, 146-157. [CrossRef]

76. Mosandl, A. Enantioselective capillary gas chromatography and stable isotope ratio mass spectrometry in the authenticity control of flavors and essential oils. Food Rev. Int. 1995, 11, 597-664. [CrossRef]

77. König, W.A.; Hochmuth, D.H. Enantioselective Gas Chromatography in Flavor and Fragrance Analysis: Strategies for the Identification of Known and Unknown Plant Volatiles. J. Chromatogr. Sci. 2004, 42, 423-439. [CrossRef] [PubMed]

78. Mosandl, A. Authenticity Assessment: A Permanent Challenge in Food Flavor and Essential Oil Analysis. J. Chromatogr. Sci. 2004, 42, 440-449. [CrossRef] [PubMed]

79. Pellati, F.; Orlandini, G.; van Leeuwen, K.A.; Anesin, G.; Bertelli, D.; Paolini, M.; Benvenuti, S.; Camin, F. Gas chromatography combined with mass spectrometry, flame ionization detection and elemental analyzer/isotope ratio mass spectrometry for characterizing and detecting the authenticity of commercial essential oils of Rosa damascena Mill. Rapid Commun. Mass Spectrom. 2013, 27, 591-602. [CrossRef]

80. Pieri, V.; Sturm, S.; Seger, C.; Franz, C.; Stuppner, H. 1H NMR-based metabolic profiling and target analysis: A combined approach for the quality control of Thymus vulgaris. Metabolomics 2012, 8, 335-346. [CrossRef]

81. Marsili, R. Sensory-Directed Flavor Analysis; CRC Press: Boca Raton, FL, USA, 2007.

82. Mitsui, T. New Cosmetic Science; Elsevier: Amsterdam, The Netherlands, 1997.

83. Cuchet, A.; Anchisi, A.; Schiets, F.; Clément, Y.; Lantéri, P.; Bonnefoy, C.; Jame, P.; Carénini, E.; Casabianca, H. Determination of enantiomeric and stable isotope ratio fingerprints of active secondary metabolites in neroli (Citrus aurantium L.) essential oils for authentication by multidimensional gas chromatography and GC-C/P-IRMS. J. Chromatogr. B 2021, 1185, 123003. [CrossRef]

84. Jentzsch, P.V.; Ramos, L.A.; Ciobotă, V. Handheld Raman Spectroscopy for the Distinction of Essential Oils Used in the Cosmetics Industry. Cosmetics 2015, 2, 162-176. [CrossRef]

85. Vargas Jentzsch, P.; Sandoval Pauker, C.; Zárate Pozo, P.; Sinche Serra, M.; Jácome Camacho, G.; Rueda-Ayala, V.; Garrido, P.; Ramos Guerrero, L.; Ciobotă, V. Raman spectroscopy in the detection of adulterated essential oils: The case of nonvolatile adulterants. J. Raman Spectrosc. 2021, 52, 1055-1063. [CrossRef]

86. Schripsema, J.; da Silva, S.M.; Dagnino, D. Differential NMR and chromatography for the detection and analysis of adulteration of vetiver essential oils. Talanta 2022, 237, 122928. [CrossRef] 
87. Massaro, A.; Negro, A.; Bragolusi, M.; Miano, B.; Tata, A.; Suman, M.; Piro, R. Oregano authentication by mid-level data fusion of chemical fingerprint signatures acquired by ambient mass spectrometry. Food Contr. 2021, 126, 108058. [CrossRef]

88. Baser, K.H.C.; Buchbauer, G. Handbook of Essential Oils: Science, Technology, and Applications; CRC Press: Boca Raton, FL, USA, 2015.

89. Butnariu, M.; Sara, I. Essential Oils from Plants. J. Biotechnol. Biomed. Sci. 2018, 1, 35-43. [CrossRef]

90. Shankar, S.; Prasad, S.; Owaiz, M.; Yadav, S.; Manhas, S.; Yaqoob, M. Essential oils, components and their applications: A review. Plant Arch. 2021, 21, 2027-2033. [CrossRef]

91. Pitman, V. Aromatherapy: A Practical Approach; Lotus Publishing: Chichester, UK, 2019.

92. Vankar, P.S. Essential oils and fragrances from natural sources. Resonance 2004, 9, 30-41. [CrossRef]

93. Burnett, C.L.; Fiume, M.M.; Bergfeld, W.F.; Belsito, D.V.; Hill, R.A.; Klaassen, C.D.; Liebler, D.C.; Marks, J.G.; Shank, R.C.; Slaga, T.J.; et al. Safety Assessment of Citrus-Derived Peel Oils as Used in Cosmetics. Int. J. Toxicol. 2019, 38, 33S-59S. [CrossRef]

94. Kynes, S. Complete Book of Essential Oils: How to Blend, Diffuse, Create Remedies, and Use in Everyday Life; Llewellyn Publications: Woodbury, MN, USA, 2019.

95. Ali, B.; Al-Wabel, N.A.; Shams, S.; Ahamad, A.; Khan, S.A.; Anwar, F. Essential oils used in aromatherapy: A systemic review. Asian Pac. J. Trop. Biomed. 2015, 5, 601-611. [CrossRef]

96. Orav, A.; Kailas, T.; Ivask, K. Volatile constituents of Matricaria recutita L. From estonia. Proc. Estonian Acad. Sci. Chem. 2001, 50, 39-45.

97. Amiri, S.; Sharafzadeh, S. Essential Oil Components of German chamomile Cultivated in Firoozabad, Iran Shahram Amiri. Orient. J. Chem 2014, 30, 365-367. [CrossRef]

98. Kamatou, G.P.P.; Viljoen, A.M. A Review of the Application and Pharmacological Properties of $\alpha$-Bisabolol and $\alpha$-Bisabolol-Rich Oils. J. Am. Oil Chem. Soc. 2010, 87, 1-7. [CrossRef]

99. Piggott, M.J.; Ghisalberti, E.L.; Trengove, R.D. Western Australian Sandalwood Oil: Extraction by Different Techniques and Variations of the Major Components in Different Sections of a Single Tree. Flavour Fragr. J. 1997, 12, 43-46. [CrossRef]

100. Misra, B.B.; Dey, S. TLC-Bioautographic Evaluation of In Vitro Anti-tyrosinase and Anti-cholinesterase Potentials of Sandalwood Oil. Nat. Prod. Comm. 2013, 8, 253-256. [CrossRef]

101. Kim, T.H.; Kim, W.J.; Park, S.Y.; Kim, H.; Chung, D.K. In Vitro Anti-Wrinkle and Skin-Moisturizing Effects of Evening Primrose (Oenothera biennis) Sprout and Identification of Its Active Components. Processes 2021, 9, 145. [CrossRef]

102. Muggli, R. Systemic evening primrose oil improves the biophysical skin parameters of healthy adults. Int. J. Cosmet. Sci. 2005, 27, 243-249. [CrossRef] [PubMed]

103. Timoszuk, M.; Bielawska, K.; Skrzydlewska, E. Evening Primrose (Oenothera biennis) Biological Activity Dependent on Chemical Composition. Antioxidants 2018, 7, 108. [CrossRef] [PubMed]

104. Li, Z.; Wang, Z.-C.; Zhang, L.-B.; Zhu, H.-L. Pharmacological Activities of Components Contained in Camellia Oil and Camellia Oil Cake and their Applications in Various Industries. Curr. Trad. Med. 2020, 6, 86-105. [CrossRef]

105. Teixeira, A.M.; Sousa, C. A Review on the Biological Activity of Camellia Species. Molecules 2021, 26, 2178. [CrossRef]

106. Shi, T.; Wu, G.; Jin, Q.; Wang, X. Camellia oil authentication: A comparative analysis and recent analytical techniques developed for its assessment. A review. Trends Food Sci. Technol. 2020, 97, 88-99. [CrossRef]

107. Salido, S.; Altarejos, J.; Nogueras, M.; Saánchez, A.; Luque, P. Chemical Composition and Seasonal Variations of Rosemary Oil from Southern Spain. J. Essent. Oil Res. 2003, 15, 10-14. [CrossRef]

108. Nieto, G.; Ros, G.; Castillo, J. Antioxidant and Antimicrobial Properties of Rosemary (Rosmarinus officinalis, L.): A Review. Medicines 2018, 5, 98. [CrossRef]

109. Froiio, F.; Ginot, L.; Paolino, D.; Lebaz, N.; Bentaher, A.; Fessi, H.; Elaissari, A. Essential Oils-Loaded Polymer Particles: Preparation, Characterization and Antimicrobial Property. Polymers 2019, 11, 1017. [CrossRef]

110. Verzera, A.; Trozzi, A.; Dugo, G.; Di Bella, G.; Cotroneo, A. Biological lemon and sweet orange essential oil composition. Flavour Fragr. J. 2004, 19, 544-548. [CrossRef]

111. Prusinowska, R.; Śmigielski, K.B. Composition, biological properties and therapeutic effects of lavender (Lavandula angustifolia L.). A review. Herba Pol. 2014, 60, 56-66. [CrossRef]

112. Oh, J.Y.; Park, M.A.; Kim, Y.C. Peppermint Oil Promotes Hair Growth without Toxic Signs. Toxicol. Res. 2014, 30, 297-304. [CrossRef]

113. Yang, S.-A.; Jeon, S.-K.; Lee, E.-J.; Shim, C.-H.; Lee, I.-S. Comparative study of the chemical composition and antioxidant activity of six essential oils and their components. Nat. Prod. Res. 2010, 24, 140-151. [CrossRef]

114. Mahboubi, M.; Kazempour, N. Chemical composition and antimicrobial activity of peppermint (Mentha piperita L.) Essential oil. Songklanakarin J. Sci. Technol. 2014, 36, 83-87.

115. Miguel, G.; Simões, M.; Figueiredo, A.C.; Barroso, J.G.; Pedro, L.G.; Carvalho, L. Composition and antioxidant activities of the essential oils of Thymus caespititius, Thymus camphoratus and Thymus mastichina. Food Chem. 2004, 86, 183-188. [CrossRef]

116. Abelan, U.S.; de Oliveira, A.C.; Cacoci, É.S.P.; Martins, T.E.A.; Giacon, V.M.; Velasco, M.V.R.; Lima, C.R.R.d.C. Potential use of essential oils in cosmetic and dermatological hair products: A review. J. Cosmet. Dermatol. 2021. [CrossRef] [PubMed]

117. Aydin, G.; Şİİ̉n, N.; Kekeçoğlu, M.; Türken, T.; Sİpahİ, N.; Göksu, H. The Use of Natural Preservative Propolis and Hypericum perforatum Oil in Herbal Cream Production. Int. J. Tradit. Complement. Med. Res. 2021, 2, $27-35$.

118. Silva Santos, A.; Antunes, A.; D'Avila, L.; Bizzo, H.; Souza-Santos, L. The Use of Essential Oils and Terpenes/Terpeneoids in Cosmetic and Perfumery. Perfum. Flavor. 2005, 30, 50-55. 
119. Aumeeruddy-Elalfi, Z.; Lall, N.; Fibrich, B.; Blom van Staden, A.; Hosenally, M.; Mahomoodally, M.F. Selected essential oils inhibit key physiological enzymes and possess intracellular and extracellular antimelanogenic properties in vitro. J. Food Drug Anal. 2018, 26, 232-243. [CrossRef]

120. Mishra, A.; Mishra, A.; Chattopadhyay, P. Assessment of In vitro Sun Protection Factor of Calendula officinalis L. (Asteraceae) Essential Oil Formulation. J. Young Pharm. 2012, 4, 17-21. [CrossRef] [PubMed]

121. Benson, H.A.E.; Roberts, M.S.; Leite-Silva, V.R.; Walters, K.A. Cosmetic Formulation Principles and Practice; CRC Press: Boca Raton, FL, USA, 2019.

122. Vangipuram, R.; Mask-Bull, L.; Kim, S.J. Cutaneous implications of essential oils. World J. Dermatol. 2017, 6, 27-31. [CrossRef]

123. Wongsukkasem, N.; Soynark, O.; Suthakitmanus, M.; Chongdiloet, E.; Chairattanapituk, C.; Vattanikitsiri, P.; Hongratanaworakit, T.; Tadtong, S. Antiacne-causing Bacteria, Antioxidant, Anti-Tyrosinase, Anti-Elastase and Anti-Collagenase Activities of Blend Essential Oil comprising Rose, Bergamot and Patchouli Oils. Nat. Prod. Comm. 2018, 13, 1934578X1801300529. [CrossRef]

124. Winkelman, W.J. Aromatherapy, botanicals, and essential oils in acne. Clin. Dermatol. 2018, 36, 299-305. [CrossRef]

125. Dreger, M.; Wielgus, K. Application of essential oils as natural cosmetic preservatives. Herba Pol. 2014, 59, 142-156. [CrossRef]

126. Arora, P.; Nanda, A.; Karan, M.; Devi, S. Shampoos based on synthetic ingredients vis-a-vis shampoos based on herbal ingredients: A review. Int. J. Pharm. Sci. Rev. Res. 2011, 7, 7.

127. Herman, A.; Herman, A.P.; Domagalska, B.W.; Młynarczyk, A. Essential Oils and Herbal Extracts as Antimicrobial Agents in Cosmetic Emulsion. Indian J. Microbiol. 2013, 53, 232-237. [CrossRef]

128. Manou, I.; Bouillard, L.; Devleeschouwer, M.J.; Barel, A.O. Evaluation of the preservative properties of Thymus vulgaris essential oil in topically applied formulations under a challenge test. J. Appl. Microbiol. 1998, 84, 368-376. [CrossRef]

129. Eid, A.M.; Elmarzugi, N.A.; Abu Ayyash, L.M.; Sawafta, M.N.; Daana, H.I. A Review on the Cosmeceutical and External Applications of Nigella sativa. J. Trop. Med. 2017, 2017, 7092514. [CrossRef] [PubMed]

130. Aburjai, T.; Natsheh, F.M. Plants used in cosmetics. Phytother. Res. 2003, 17, 987-1000. [CrossRef]

131. Hay, I.C.; Jamieson, M.; Ormerod, A.D. Randomized trial of aromatherapy. Successful treatment for alopecia areata. Arch. Dermatol. 1998, 134, 1349-1352. [CrossRef]

132. Panahi, Y.; Taghizadeh, M.; Marzony, E.T.; Sahebkar, A. Rosemary oil vs. minoxidil $2 \%$ for the treatment of androgenetic alopecia: A randomized comparative trial. Skinmed 2015, 13, 15-21.

133. Lee, G.-S.; Hong, E.-J.; Gwak, K.-S.; Park, M.-J.; Choi, K.-C.; Choi, I.-G.; Jang, J.-W.; Jeung, E.-B. The essential oils of Chamaecyparis obtusa promote hair growth through the induction of vascular endothelial growth factor gene. Fitoterapia 2010, 81, 17-24. [CrossRef]

134. Ravichandran, G.; Bharadwaj, V.S.; Kolhapure, S.A. Evaluation of the clinical efficacy and safety of "Anti-Dandruff Shampoo" in the treatment of dandruff. Antiseptic 2004, 201, 5-8.

135. Halith, S.M.; Abirami, A.; Jayaprakash, S.; Karthikeyini, C.; Pillai, K.K.; Firthouse, P.U.M. Effect of Ocimum sanctum and Azadiracta indica on the formulation of antidandruff herbal shampoo powder. Der Pharm. Lett. 2009, 1, 68-76.

136. Lee, J.-H.; Lee, J.-S. Chemical Composition and Antifungal Activity of Plant Essential Oils against Malassezia furfur. Microbiol. Biotech. Lett. 2010, 38, 315-321.

137. Muyima, N.Y.O.; Zulu, G.; Bhengu, T.; Popplewell, D. The potential application of some novel essential oils as natural cosmetic preservatives in an aqueous cream formulation. Flavour Fragr. J. 2002, 17, 258-266. [CrossRef]

138. Beri, K. Perspective: Stabilizing the Microbiome Skin-Gut-Brain Axis with Natural Plant Botanical Ingredients in Cosmetics. Cosmetics 2018, 5, 37. [CrossRef]

139. Wińska, K.; Mączka, W.; Łyczko, J.; Grabarczyk, M.; Czubaszek, A.; Szumny, A. Essential Oils as Antimicrobial Agents-Myth or Real Alternative? Molecules 2019, 24, 2130. [CrossRef] [PubMed]

140. Sahraie-Rad, M.; Izadyari, A.; Rakizadeh, S.; Sharifi-Rad, J. Preparation of Strong Antidandruff Shampoo Using Medicinal Plant Extracts: A Clinical Trial and Chronic Dandruff Treatment. Jundishapur J. Nat. Pharm. Prod. 2015, 10, e21517. [CrossRef]

141. Happy, A.A.; Jahan, F.; Momen, M.A. Essential Oils: Magical Ingredients for Skin Care. J. Plant Sci. 2021, 9, 54-64. [CrossRef]

142. Lertsatitthanakorn, P.; Taweechaisupapong, S.; Aromdee, C.; Khunkitti, W. In vitro bioactivities of essential oils used for acne control. Int. J. Aromath. 2006, 16, 43-49. [CrossRef]

143. Tao, K.; Guo, L.; Fernandez, J.; Webb, C.; Liu, J.; Hu, X.; Yang, D.; Perez, E. Artemisia Naphta: A novel oil extract for sensitive and acne prone skin. Ann. Dermatol. Res. 2021, 5, 22-29. [CrossRef]

144. Mahant, S.; Sahajpal, N.S.; Nanda, S. Insights into the mechanism of Cymbopogan martinii essential oil in topical therapy of acne vulgaris. Future Microbiol. 2021, 16, 1181-1193. [CrossRef]

145. Xiao, S.; Yu, H.; Xie, Y.; Guo, Y.; Fan, J.; Yao, W. The anti-inflammatory potential of Cinnamomum camphora (L.) J. Presl essential oil in vitro and in vivo. J. Ethnopharmacol. 2021, 267, 113516. [CrossRef]

146. Nawarathne, N.W.; Wijesekera, K.; Wijayaratne, W.M.D.G.B.; Napagoda, M. Development of Novel Topical Cosmeceutical Formulations from Nigella sativa L. with Antimicrobial Activity against Acne-Causing Microorganisms. Sci. World J. 2019, 2019, 5985207. [CrossRef] [PubMed]

147. Boukhatem, M.N.; Kameli, A.; Ferhat, M.A.; Saidi, F.; Mekarnia, M. Rose geranium essential oil as a source of new and safe anti-inflammatory drugs. Libyan J. Med. 2013, 8, 22520. [CrossRef] [PubMed]

148. Sinha, P.; Srivastava, S.; Mishra, N.; Yadav, N.P. New perspectives on antiacne plant drugs: Contribution to modern therapeutics. BioMed Res. Int. 2014, 2014, 301304. [CrossRef] [PubMed] 
149. Rahmi, D.; Yunilawati, R.; Jati, B.N.; Setiawati, I.; Riyanto, A.; Batubara, I.; Astuti, R.I. Antiaging and Skin Irritation Potential of Four Main Indonesian Essential Oils. Cosmetics 2021, 8, 94. [CrossRef]

150. Elgamal, A.M.; Ahmed, R.F.; Abd-ElGawad, A.M.; El Gendy, A.E.-N.G.; Elshamy, A.I.; Nassar, M.I. Chemical Profiles, Anticancer, and Anti-Aging Activities of Essential Oils of Pluchea dioscoridis (L.) DC. and Erigeron bonariensis L. Plants 2021, 10, 667. [CrossRef]

151. Tu, P.T.B.; Tawata, S. Anti-Oxidant, Anti-Aging, and Anti-Melanogenic Properties of the Essential Oils from Two Varieties of Alpinia zerumbet. Molecules 2015, 20, 16723-16740. [CrossRef]

152. Ben Hsouna, A.; Ben Halima, N.; Smaoui, S.; Hamdi, N. Citrus lemon essential oil: Chemical composition, antioxidant and antimicrobial activities with its preservative effect against Listeria monocytogenes inoculated in minced beef meat. Lipids Health Dis. 2017, 16, 146. [CrossRef]

153. de Andrade, S.F.; Rijo, P.; Rocha, C.; Zhu, L.; Rodrigues, L.M. Characterizing the Mechanism of Action of Essential Oils on Skin Homeostasis-Data from Sonographic Imaging, Epidermal Water Dynamics, and Skin Biomechanics. Cosmetics 2021, 8, 36. [CrossRef]

154. Phetcharat, L.; Wongsuphasawat, K.; Winther, K. The effectiveness of a standardized rose hip powder, containing seeds and shells of Rosa canina, on cell longevity, skin wrinkles, moisture, and elasticity. Clin. Interv. Aging 2015, 10, 1849-1856. [CrossRef] [PubMed]

155. Lin, R.-F.; Feng, X.-X.; Li, C.-W.; Zhang, X.-J.; Yu, X.-T.; Zhou, J.-Y.; Zhang, X.; Xie, Y.-L.; Su, Z.-R.; Zhan, J.Y.-X. Prevention of UV radiation-induced cutaneous photoaging in mice by topical administration of patchouli oil. J. Ethnopharmacol. 2014, 154, 408-418. [CrossRef]

156. Tan, L.T.; Lee, L.H.; Yin, W.F.; Chan, C.K.; Abdul Kadir, H.; Chan, K.G.; Goh, B.H. Traditional Uses, Phytochemistry, and Bioactivities of Cananga odorata (Ylang-Ylang). Evid. Based Complement. Alternat. Med. 2015, 2015, 896314. [CrossRef]

157. Ao, Y.; Satoh, K.; Shibano, K.; Kawahito, Y.; Shioda, S. Singlet oxygen scavenging activity and cytotoxicity of essential oils from rutaceae. J. Clin. Biochem. Nutr. 2008, 43, 6-12. [CrossRef]

158. Dabrowska, M.; Maciejczyk, E.; Kalemba, D. Rose Hip Seed Oil: Methods of Extraction and Chemical Composition. Eur. J. Lipid Sci. Technol. 2019, 121, 1800440. [CrossRef]

159. Fukada, M.; Kano, E.; Miyoshi, M.; Komaki, R.; Watanabe, T. Effect of "rose essential oil" inhalation on stress-induced skin-barrier disruption in rats and humans. Chem. Senses 2012, 374, 347-356. [CrossRef]

160. Mohebitabar, S.; Shirazi, M.; Bioos, S.; Rahimi, R.; Malekshahi, F.; Nejatbakhsh, F. Therapeutic efficacy of rose oil: A comprehensive review of clinical evidence. Avicenna J. Phytomed. 2017, 7, 206-213. [PubMed]

161. Saraf, S. Formulating Moisturizers Using Natural Raw Materials. In Treatment of Dry Skin Syndrome: The Art and Science of Moisturizers; Lodén, M., Maibach, H.I., Eds.; Springer: Berlin/Heidelberg, Germany, 2012; pp. 379-397. [CrossRef]

162. Varothai, S.; Nitayavardhana, S.; Kulthanan, K. Moisturizers for patients with atopic dermatitis. Asian Pac. J. Allergy Immunol. 2013, 31, 91-98.

163. Lohani, A.; Mishra, A.K.; Verma, A. Cosmeceutical potential of geranium and calendula essential oil: Determination of antioxidant activity and in vitro sun protection factor. J. Cosmet. Dermatol. 2019, 18, 550-557. [CrossRef] [PubMed]

164. Mansur, J.d.S.; Breder, M.N.R.; Mansur, M.C.d.A.; Azulay, R.D. Determinaçäo do fator de proteçäo solar por espectrofotometria/Determination of sun protection factor by spectrophotometry. An. Bras. Dermatol. 1986, 61, 121-124.

165. Kaur, C.D.; Saraf, S. In vitro sun protection factor determination of herbal oils used in cosmetics. Pharmacognosy Res. 2010, 2, 22-25. [CrossRef]

166. Kale, S.; Sonawane, A.; Ansari, A.; Ghoge, P.; Waje, A. Formulation and in-vitro determination of sun protection factor of Ocimum basilicum, Linn. leaf oils sunscreen cream. Int. J. Pharm. Pharm. Sci. 2010, 2, 147-149.

167. Adewinogo, S.O.; Sharma, R.; Africa, C.W.J.; Marnewick, J.L.; Hussein, A.A. Chemical Composition and Cosmeceutical Potential of the Essential Oil of Oncosiphon suffruticosum (L.) Källersjö. Plants 2021, 10, 1315. [CrossRef]

168. Kamairudin, N.; Gani, S.S.A.; Masoumi, H.R.F.; Hashim, P. Optimization of Natural Lipstick Formulation Based on Pitaya (Hylocereus polyrhizus) Seed Oil Using D-Optimal Mixture Experimental Design. Molecules 2014, 19, 16672-16683. [CrossRef] [PubMed]

169. Afandi, A.; Lazim, A.M.; Azwanida, N.N.; Bakar, M.A.; Airianah, O.B.; Fazry, S. Antibacterial properties of crude aqueous Hylocereus polyrhizus peel extracts in lipstick formulation against gram-positive and negative bacteria. Malays. Appl. Biol. 2017, 46, 29-34.

170. Vats, M.; Sharma, T.; Sharma, G.; Kumar, S.; Sharma, J.; Sharma, S.; Mangla, B. The synthesis, characterization and application of cobalt ferrite nanoparticles in lipstick. AIP Conf. Proc. 2020, 2220, 020119. [CrossRef]

171. Maktabi, B.; Liberatore, M.W.; Baki, G. Meadowfoam seed oil as a natural dispersing agent for colorants in lipstick. Int. J. Cosmet. Sci. 2021, 43, 484-493. [CrossRef]

172. Andersen, K.E. Contact allergy and irritation from preservatives. J. Appl. Cosmetol. 1993, 11, 65-68.

173. Mangena, T.; Muyima, N.Y.O. Comparative evaluation of the antimicrobial activities of essential oils of Artemisia afra, Pteronia incana and Rosmarinus officinalis on selected bacteria and yeast strains. Lett. Appl. Microbiol. 1999, 28, 291-296. [CrossRef] [PubMed]

174. Halla, N.; Fernandes, I.P.; Heleno, S.A.; Costa, P.; Boucherit-Otmani, Z.; Boucherit, K.; Rodrigues, A.E.; Ferreira, I.C.F.R.; Barreiro, M.F. Cosmetics Preservation: A Review on Present Strategies. Molecules 2018, 23, 1571. [CrossRef] 
175. Li, Z.Z.; Chen, J.F.; Liu, F.; Liu, A.Q.; Wang, Q.; Sun, H.Y.; Wen, L.X. Study of UV-shielding properties of novel porous hollow silica nanoparticle carriers for avermectin. Pest Manag. Sci. 2007, 63, 241-246. [CrossRef] [PubMed]

176. Wibowo, D.; Zhao, C.-X.; Peters, B.C.; Middelberg, A.P.J. Sustained Release of Fipronil Insecticide In Vitro and In Vivo from Biocompatible Silica Nanocapsules. J. Agric. Food Chem. 2014, 62, 12504-12511. [CrossRef]

177. Kah, M.; Kookana, R.S.; Gogos, A.; Bucheli, T.D. A critical evaluation of nanopesticides and nanofertilizers against their conventional analogues. Nat. Nanotechnol. 2018, 13, 677-684. [CrossRef]

178. Lucia, A.; Argudo, P.G.; Guzmán, E.; Rubio, R.G.; Ortega, F. Formation of surfactant free microemulsions in the ternary system water/eugenol/ethanol. Colloids Surf. A 2017, 521, 133-140. [CrossRef]

179. Argudo, P.G.; Guzmán, E.; Lucia, A.; Rubio, R.G.; Ortega, F. Preparation and Application in Drug Storage and Delivery of Agarose Nanoparticles. Int. J. Polym. Sci. 2018, 2018, 7823587. [CrossRef]

180. Fernández-Peña, L.; Gutiérrez-Muro, S.; Guzmán, E.; Lucia, A.; Ortega, F.; Rubio, G.R. Oil-in-Water Microemulsions for Thymol Solubilization. Colloids Interfaces 2019, 3, 64. [CrossRef]

181. Sánchez-Arribas, N.; Guzmán, E.; Lucia, A.; Toloza, A.C.; Velarde, M.G.; Ortega, F.; Rubio, R.G. Environmentally friendly platforms for encapsulation of an essential oil: Fabrication, characterization and application in pests control. Colloids Surf. A 2018, 555, 473-481. [CrossRef]

182. Guzmán, E.; Mateos-Maroto, A.; Ruano, M.; Ortega, F.; Rubio, R.G. Layer-by-Layer polyelectrolyte assemblies for encapsulation and release of active compounds. Adv. Colloid Interface Sci. 2017, 249, 290-307. [CrossRef]

183. Babaoglu, H.C.; Bayrak, A.; Ozdemir, N.; Ozgun, N. Encapsulation of clove essential oil in hydroxypropyl beta-cyclodextrin for characterization, controlled release, and antioxidant activity. J. Food Process. Preserv. 2017, 41, e13202. [CrossRef]

184. Medina-Pérez, G.; Fernández-Luqueño, F.; Campos-Montiel, R.G.; Sánchez-López, K.B.; Afanador-Barajas, L.N.; Prince, L. Nanotechnology in crop protection: Status and future trends. In Nano-Biopesticides Today and Future Perspectives; Koul, O., Ed.; Academic Press: New York, NY, USA, 2019; pp. 17-45. [CrossRef]

185. Ruano, M.; Mateos-Maroto, A.; Ortega, F.; Ritacco, H.; Rubio, J.E.F.; Guzmán, E.; Rubio, R.G. Fabrication of Robust Capsules by Sequential Assembly of Polyelectrolytes onto Charged Liposomes. Langmuir 2021, 37, 6189-6200. [CrossRef]

186. Lucia, A.; Guzmán, E.; Rubio, R.G.; Ortega, F. Enhanced solubilization of an insect juvenile hormone (JH) mimetic (piryproxyfen) using eugenol in water nanoemulsions stabilized by a triblock copolymer of poly(ethylenglycol) and poly(propilenglycol). Colloids Surf. A 2020, 606, 125513. [CrossRef]

187. Pavela, R.; Benelli, G. Essential Oils as Ecofriendly Biopesticides? Challenges and Constraints. Trends Plant Sci. 2016, 21, 1000-1007. [CrossRef]

188. Isman, M.B.; Miresmailli, S.; Machial, C. Commercial opportunities for pesticides based on plant essential oils in agriculture, industry and consumer products. Phytochem. Rev. 2011, 10, 197-204. [CrossRef]

189. Regnault-Roger, C.; Vincent, C.; Arnason, J.T. Essential Oils in Insect Control: Low-Risk Products in a High-Stakes World. Ann. Rev. Entomol. 2011, 57, 405-424. [CrossRef]

190. Pivetta, T.P.; Simões, S.; Araújo, M.M.; Carvalho, T.; Arruda, C.; Marcato, P.D. Development of nanoparticles from natural lipids for topical delivery of thymol: Investigation of its anti-inflammatory properties. Colloids Surf. B 2018, 164, 281-290. [CrossRef]

191. Hosseini, S.F.; Zandi, M.; Rezaei, M.; Farahmandghavi, F. Two-step method for encapsulation of oregano essential oil in chitosan nanoparticles: Preparation, characterization and in vitro release study. Carbohydr. Polym. 2013, 95, 50-56. [CrossRef]

192. Tiwari, S.; Singh, B.; Dubey, N. Encapsulation of Essential Oils-A Booster to Enhance their Bio-efficacy as Botanical Preservatives. J. Sci. Res. 2020, 64, 175-178. [CrossRef]

193. Cáceres, M.; Guzmán, E.; Alvarez-Costa, A.; Ortega, F.; Rubio, G.R.; Coviella, C.; Santo Orihuela, P.L.; Vassena, C.V.; Lucia, A. Surfactantless Emulsions Containing Eugenol for Imidacloprid Solubilization: Physicochemical Characterization and Toxicity against Insecticide-Resistant Cimex lectularius. Molecules 2020, 25, 2290. [CrossRef]

194. Marques, H.C. Applications of cyclodextrins. Thermodynamic aspects of cyclodextrin complexes. Rev. Port. Farm. 1994, $44,85-96$.

195. Marques, H.M.C. A review on cyclodextrin encapsulation of essential oils and volatiles. Flavour Fragr. J. 2010, 25, 313-326. [CrossRef]

196. Lucia, A.; Toloza, A.C.; Fanucce, M.; Fernández-Peña, L.; Ortega, F.; Rubio, R.G.; Coviella, C.; Guzmán, E. Nanoemulsions based on thymol-eugenol mixtures: Characterization, stability and larvicidal activity against Aedes aegypti. Bull. Insectol. 2020, 73, 153-160.

197. Lucia, A.; Girard, C.; Fanucce, M.; Coviella, C.; Rubio, R.G.; Ortega, F.; Guzmán, E. Development of an Environmentally Friendly Larvicidal Formulation Based on Essential Oil Compound Blend to Control Aedes aegypti Larvae: Correlations between Physicochemical Properties and Insecticidal Activity. ACS Sustain. Chem. Eng. 2020, 8, 10995-11006. [CrossRef]

198. Fernandes, R.V.d.B.; Borges, S.V.; Botrel, D.A. Gum arabic/starch/maltodextrin/inulin as wall materials on the microencapsulation of rosemary essential oil. Carbohydr. Polym. 2014, 101, 524-532. [CrossRef]

199. Krishnan, S.; Bhosale, R.; Singhal, R.S. Microencapsulation of cardamom oleoresin: Evaluation of blends of gum arabic, maltodextrin and a modified starch as wall materials. Carbohydr. Polym. 2005, 61, 95-102. [CrossRef]

200. Kanakdande, D.; Bhosale, R.; Singhal, R.S. Stability of cumin oleoresin microencapsulated in different combination of gum arabic, maltodextrin and modified starch. Carbohydr. Polym. 2007, 67, 536-541. [CrossRef]

201. Lucia, A.; Murace, M.; Sartor, G.; Keil, G.; Cámera, R.; Rubio, R.G.; Guzmán, E. Oil in Water Nanoemulsions Loaded with Tebuconazole for Populus Wood Protection against White- and Brown-Rot Fungi. Forests 2021, 12, 1234. [CrossRef] 
202. Guzmán, E.; Fernández-Peña, L.; Rossi, L.; Bouvier, M.; Ortega, F.; Rubio, R.G. Nanoemulsions for the Encapsulation of Hydrophobic Actives. Cosmetics 2021, 8, 45. [CrossRef]

203. Mateos-Maroto, A.; Abelenda-Núñez, I.; Ortega, F.; Rubio, R.G.; Guzmán, E. Polyelectrolyte Multilayers on Soft Colloidal Nanosurfaces: A New Life for the Layer-By-Layer Method. Polymers 2021, 13, 1221. [CrossRef] [PubMed]

204. Srivastava, M.P.; Fatima, A. Essential Oils (Eos) as the Advantages of its Micro-encapsulation in Cosmetic Industry. G-J. Environ. Sci. Technol. 2021, 8, 28-42.

205. Martins, I.M.; Barreiro, M.F.; Coelho, M.; Rodrigues, A.E. Microencapsulation of essential oils with biodegradable polymeric carriers for cosmetic applications. Chem. Eng. J. 2014, 245, 191-200. [CrossRef]

206. Rodríguez, J.; Martín, M.J.; Ruiz, M.A.; Clares, B. Current encapsulation strategies for bioactive oils: From alimentary to pharmaceutical perspectives. Food Res. Int. 2016, 83, 41-59. [CrossRef]

207. Mamusa, M.; Resta, C.; Sofroniou, C.; Baglioni, P. Encapsulation of volatile compounds in liquid media: Fragrances, flavors, and essential oils in commercial formulations. Adv. Colloid Interface Sci. 2021, 298, 102544. [CrossRef] [PubMed]

208. Park, S.-J.; Shin, Y.-S.; Lee, J.-R. Preparation and Characterization of Microcapsules Containing Lemon Oil. J. Colloid Interface Sci. 2001, 241, 502-508. [CrossRef]

209. Weinbreck, F.; Minor, M.; de Kruif, C.G. Microencapsulation of oils using whey protein/gum arabic coacervates. J. Microencapsul. 2004, 21, 667-679. [CrossRef]

210. Martins, I.M.; Rodrigues, S.N.; Barreiro, F.; Rodrigues, A.E. Microencapsulation of thyme oil by coacervation. J. Microencaps. 2009, 26, 667-675. [CrossRef]

211. Gumí, T.; Gascón, S.; Torras, C.; Garcia-Valls, R. Vanillin release from macrocapsules. Desalination 2009, 245, 769-775. [CrossRef]

212. Shahtalebi, M.; Sadat-Hosseini, A.; Safaeian, L. Preparation and evaluation of clove oil in emu oil self-emulsion for hair conditioning and hair loss prevention. J. HerbMed Pharmacol. 2016, 5, 72-77.

213. Anchisi, C.; Meloni, M.C.; Maccioni, A.M. Chitosan beads loaded with essential oils in cosmetic formulations. J. Cosmet. Sci. 2006, 57, 205-214. [CrossRef] [PubMed]

214. Liu, Y.; Liu, M.; Zhao, J.; Wang, D.; Zhang, L.; Wang, H.; Cao, W.; Wang, S. Microencapsulation of Osmanthus essential oil by interfacial polymerization: Optimization, characterization, release kinetics, and storage stability of essential oil from microcapsules. J. Food Sci. 2021. [CrossRef]

215. Liu, C.; Liang, B.; Wang, Y.; Li, Y.; Shi, G. Core-shell nanocapsules containing essential oil for textile application. J. Appl. Polym. Sci. 2018, 135, 45695. [CrossRef]

216. Cobb, J.S.; Chapusha, C.; Gaikwad, J.; Michael, J.; Janorkar, A.V. Polymer micro-particles formed by thiol-ene suspension polymerization using canola oil as a diluent solvent. Mat. Adv. 2021, 2, 3378-3384. [CrossRef]

217. Varona, S.; Martín, Á.; Cocero, M.J. Formulation of a natural biocide based on lavandin essential oil by emulsification using modified starches. Chem. Eng. Process. Process Intens. 2009, 48, 1121-1128. [CrossRef]

218. Wadhwa, G.; Kumar, S.; Mittal, V.; Rao, R. Encapsulation of babchi essential oil into microsponges: Physicochemical properties, cytotoxic evaluation and anti-microbial activity. J. Food Drug Anal. 2019, 27, 60-70. [CrossRef]

219. Vega, O.; Araya, J.J.; Chavarría, M.; Castellón, E. Antibacterial biocomposite materials based on essential oils embedded in sol-gel hybrid silica matrices. J. Sol-Gel Sci. Technol. 2016, 79, 584-595. [CrossRef]

220. Akolade, J.O.; Nasir-Naeem, K.O.; Swanepoel, A.; Yusuf, A.A.; Balogun, M.; Labuschagne, P. $\mathrm{CO}_{2}$-assisted production of

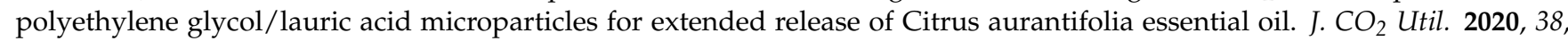
375-384. [CrossRef]

221. Raeisi, S.; Ojagh, S.M.; Quek, S.Y.; Pourashouri, P.; Salaün, F. Nano-encapsulation of fish oil and garlic essential oil by a novel composition of wall material: Persian gum-chitosan. LWT 2019, 116, 108494. [CrossRef]

222. Jang, S.H.; Jang, S.R.; Lee, G.M.; Ryu, J.H.; Park, S.I.; Park, N.H. Halloysite Nanocapsules Containing Thyme Essential Oil: Preparation, Characterization, and Application in Packaging Materials. J. Food Sci. 2017, 82, 2113-2120. [CrossRef]

223. Matulyte, I.; Kasparaviciene, G.; Bernatoniene, J. Development of New Formula Microcapsules from Nutmeg Essential Oil Using Sucrose Esters and Magnesium Aluminometasilicate. Pharmaceutics 2020, 12, 628. [CrossRef] [PubMed]

224. Bashiri, S.; Ghanbarzadeh, B.; Ayaseh, A.; Dehghannya, J.; Ehsani, A. Preparation and characterization of chitosan-coated nanostructured lipid carriers (CH-NLC) containing cinnamon essential oil for enriching milk and anti-oxidant activity. LWT 2020, 119, 108836. [CrossRef]

225. Aguiar, M.C.S.; das Graças Fernandes da Silva, M.F.; Fernandes, J.B.; Forim, M.R. Evaluation of the microencapsulation of orange essential oil in biopolymers by using a spray-drying process. Sci. Rep. 2020, 10, 11799. [CrossRef]

226. Beirão-da-Costa, S.; Duarte, C.; Bourbon, A.I.; Pinheiro, A.C.; Januário, M.I.N.; Vicente, A.A.; Beirão-da-Costa, M.L.; Delgadillo, I. Inulin potential for encapsulation and controlled delivery of Oregano essential oil. Food Hydrocolloids 2013, 33, 199-206. [CrossRef]

227. Velázquez-Contreras, C.; Osorio-Revilla, G.; Gallardo-Velázquez, T. Encapsulation of Orange Essential Oil in a Spout-Fluid Bed Dryer with a Draft Tube on a Bed of Inert Solids. Dry. Technol. 2014, 32, 1718-1726. [CrossRef]

228. Dolcà, C.; Ferránndiz, M.; Capablanca, L.; Franco, E.; Mira, E.; López, F.; García, D. Microencapsulation of Rosemary Essential Oil by Co-Extrusion/Gelling Using Alginate as a Wall Material. J. Encapsulation Adsorpt. Sci. 2015, 5, 121-130. [CrossRef]

229. Varona, S.; Martín, Á.; Cocero, M.J.; Duarte, C.M.M. Encapsulation of Lavandin Essential Oil in Poly-( $\epsilon$-caprolactones) by PGSS Process. Chem. Eng. Technol. 2013, 36, 1187-1192. [CrossRef] 
230. Herman, A. Antimicrobial Ingredients as Preservative Booster and Components of Self-Preserving Cosmetic Products. Curr. Microbiol. 2019, 76, 744-754. [CrossRef]

231. Gontar, L.; Herman, A.; Osinska, E. Monarda essential oils as natural cosmetic preservative systems. Nat. Volatiles Essent. Oils 2021, 8, 29-38. [CrossRef]

232. de Groot, A.C.; Schmidt, E. Essential Oils, Part I: Introduction. Dermatitis 2016, 27, 39-42. [CrossRef]

233. Wolffenbüttel, A.N. Base da Química dos Óleos Essenciais e Aromaterapia: Abordagem Técnica e Científica; Editora Laszlo: São Paulo, Brasil, 2020.

234. Singh, V.K. Essential Oil History, Use and Production: A Review. Cosmet. Toilet. 2019, 134, 60-68.

235. Cunha, A.P.d.; Nogueira, M.T.; Roque, O.R.; Barroso, J.M.G. Plantas Aromáticas e óleos Essenciais: Composição e Aplicações; Fundação Calouste Gulbenkian: Lisboa, Portugal, 2012.

236. Da Silva, A.R. Aromaterapia em Dermatologia e Estética; Roca: Sao Paulo, Brasil, 2004.

237. Jack, A.R.; Norris, P.L.; Storrs, F.J. Allergic contact dermatitis to plant extracts in cosmetics. Semin. Cutan. Med. Surg. 2013, 32, 140-146. [CrossRef]

238. Herro, E.; Jacob, S.E. Mentha piperita (peppermint). Dermatitis 2010, 21, 327-329. [CrossRef]

239. Warshaw, E.M.; Maibach, H.I.; Taylor, J.S.; Sasseville, D.; DeKoven, J.G.; Zirwas, M.J.; Fransway, A.F.; Mathias, C.G.; Zug, K.A.; DeLeo, V.A.; et al. North American contact dermatitis group patch test results: 2011-2012. Dermatitis 2015, 26, 49-59. [CrossRef]

240. Higgins, C.; Palmer, A.; Nixon, R. Eucalyptus oil: Contact allergy and safety. Contact Dermat. 2015, 72, 344-346. [CrossRef] [PubMed]

241. Gyldenløve, M.; Menné, T.; Thyssen, J.P. Eucalyptus contact allergy. Contact Dermat. 2014, 71, 303-304. [CrossRef] [PubMed]

242. Hagvall, L.; Berglund, V.; Bråred Christensson, J. Air-oxidized linalyl acetate-An emerging fragrance allergen? Contact Dermat. 2015, 72, 216-223. [CrossRef]

243. Saedi, N.; Crawford, G. Botanical briefs: Ylang-ylang oil-Extracts from the tree Cananga odorata. Cutis 2006, 77, 149-150. [PubMed]

244. Crawford, G.H.; Katz, K.A.; Ellis, E.; James, W.D. Use of aromatherapy products and increased risk of hand dermatitis in massage therapists. Arch. Dermatol. 2004, 140, 991-996. [CrossRef]

245. Sugiura, M.; Hayakawa, R.; Kato, Y.; Sugiura, K.; Hashimoto, R. Results of patch testing with lavender oil in Japan. Contact Dermat. 2000, 43, 157-160. [CrossRef]

246. Wu, P.A.; James, W.D. Lavender. Dermatitis 2011, 22, 344-347. [CrossRef] 